\title{
First lacustrine varve chronologies from Mexico: impact of droughts, ENSO and human activity since AD 1840 as recorded in maar sediments from Valle de Santiago
}

\author{
Ulrike Kienel · Sabine Wulf Bowen · Roger Byrne · Jungjae Park • \\ Harald Böhnel · Peter Dulski · James F. Luhr $\cdot$ Lee Siebert \\ Gerald H. Haug · Jörg F. W. Negendank
}

Received: 19 March 2008/Accepted: 1 January 2009/Published online: 24 February 2009

(C) The Author(s) 2009. This article is published with open access at Springerlink.com

\begin{abstract}
We present varve chronologies for sediments from two maar lakes in the Valle de Santiago region (Central Mexico): Hoya La Alberca (AD 18521973) and Hoya Rincón de Parangueo (AD 1839-1943). These are the first varve chronologies for Mexican lakes. The varved sections were anchored with tephras from Colima (1913) and Paricutín (1943/1944) and ${ }^{210} \mathrm{~Pb}$ ages. We compare the sequences using the thickness of seasonal laminae and element counts (Al, Si, S, Cl, K, Ti, Mn, Fe, and Sr) determined by micro X-ray fluorescence spectrometry. The formation
\end{abstract}

This paper is dedicated to our colleague and friend Jim Luhr, Director of the Smithsonian's Global Volcanism Program and aficionado of Mexican volcanoes, who unexpectedly passed away on 1 January 2007.

U. Kienel $(\bowtie) \cdot$ S. W. Bowen · P. Dulski ·

J. F. W. Negendank

Helmholtz Centre Potsdam GFZ German Research Centre

for Geosciences, Section. 3.3 Climate Dynamics and

Sediments, Telegrafenberg Haus C, 14473 Potsdam,

Germany

e-mail: ukienel@gfz-potsdam.de

S. W. Bowen

Institute for Geophysics, Jackson School of Geosciences, University of Texas at Austin, J.J. Pickle Research Campus, Bldg. 196, 10100 Burnet Rd., Austin, TX 78758-4445, USA

R. Byrne · J. Park

Geography Department, University of California at Berkeley, 507 McCone Hall, Berkeley, CA 94720, USA of the varve sublaminae is attributed to the strongly seasonal climate regime. Limited rainfall and high evaporation rates in winter and spring induce precipitation of carbonates (high $\mathrm{Ca}, \mathrm{Sr}$ ) enriched in ${ }^{13} \mathrm{C}$ and ${ }^{18} \mathrm{O}$, whereas rainfall in summer increases organic and clastic input (plagioclase, quartz) with high counts of lithogenic elements (K, $\mathrm{Al}, \mathrm{Ti}$, and $\mathrm{Si})$. Eolian input of $\mathrm{Ti}$ occurs also in the dry season. Moving correlations (5-yr windows) of the $\mathrm{Ca}$ and $\mathrm{Ti}$ counts show similar development in both sequences until the 1930s. Positive correlations indicate mixing of allochthonous $\mathrm{Ti}$ and autochthonous $\mathrm{Ca}$, while negative correlations indicate their separation in sublaminae. Negative excursions in the correlations correspond with historic and reconstructed droughts, El Niño events, and

H. Böhnel

Centro de Geociencias, Campus UNAM Juriquilla, 76230 Queretaro, Mexico

J. F. Luhr · L. Siebert

Department of Mineral Sciences, NHB-119, Smithsonian Institution, P.O. Box 37012, Washington,

DC 20013-7012, USA

U. Kienel · G. H. Haug

Leibniz Center for Earth Surface and Climate Dynamics, Universität Potsdam, Institut für Geowissenschaften,

Karl-Liebknecht-Strasse 24, Haus 27, 14476 Golm, Germany

G. H. Haug

ETH Zürich, Climate Geology, Universitätsstrasse 6, 8092 Zurich, Switzerland 
positive SST anomalies. Based on our data, droughts (3-7 year duration) were severe and centred around the following years: the early 1850s, 1865, 1880, 1895, 1905,1915 and the late 1920s with continuation into the 1930s. The latter dry period brought both lake systems into a critical state making them susceptible to further drying. Groundwater overexploitation due to the expansion of irrigation agriculture in the region after 1940 induced the transition from calcite to aragonite precipitation in Alberca and halite infiltration in Rincón. The proxy data indicate a faster response to increased evaporation for Rincón, the lake with the larger maar dimensions, solar radiation receipt and higher conductivity, whereas the smaller, steeper Alberca maar responded rapidly to increased precipitation.

Keywords Varve chronology - Tephra - Element chemistry · Drought · Human impact · El Niño · Mexico

\section{Introduction}

Only a few high-resolution paleolimnological studies have been carried out in Mexico and none with subdecadal resolution (e.g. Caballero et al. 2006; Davies et al. 2004; Metcalfe 1995; Metcalfe et al. 1989, 2000; Park et al. under review). This resolution is insufficient for testing proposed mechanisms for climatic variability, such as solar cycles or ENSO (Metcalfe and Davies 2007). Several studies in other parts of the world have shown that calibration of the paleolimnological record is possible provided that the chronology is accurate and of annual resolution at least (e.g. Brooks and Birks 2000; Moore et al. 2001).

The maar lakes of the Trans-Mexican Volcanic Belt (TMVB) provide promising locations for high-resolution paleolimnological studies because maar lake sediments are often seasonally laminated, i.e. varved (e.g. Brauer et al. 1999; Kienel et al. 2005; Schettler et al. 2006; Zolitschka et al. 2000). The varving is in part due to the maar topography which typically involves steep crater walls and a low lake surface/lake depth ratio; this minimizes wind action and overturning of the water column. Varve sublaminae form as a consequence of contrasting seasonal conditions. In the Valle the Santiago region, the climate is strongly seasonal with respect to precipitation and evaporation.
Up to $90 \%$ of the annual rainfall occurs during the rainy season (May to October) and the dryness of the dry season (November to April) is accentuated by high evaporation rates.

Tephra layers are common in the sediments of lakes in the TMVB and provide an important additional means of age control (Davies et al. 2004; Newton et al. 2005; Ortega-Guerrero and Newton 1998).

Reports of direct (weather-related) or indirect (harvests, prices, diseases, famines) evidence of historic weather conditions are published for Chihuahua, Michoacán, the Basin of Mexico, and Guanajuato (Endfield and O'Hara 1999; Endfield and Fernandez Tejedo 2006; O’Hara 1993; Metcalfe 1987). Much of this information was collected from colonial archives. Florescano and Swan (1995) compiled historic evidence for the period $1500 \mathrm{BC}-1977 \mathrm{AD}$ and Escobar Ohmstede (2004) for the period 1822-1900. Concerning instrumental data, there are only three weather stations in Mexico (Tacubaya, Guadalajara, and Chihuahua) with continuous records that extend back to the early years of the last century. Most stations, there are more than 600 in total, have records that only date back to the 1920s or 1930s, and many of these are not continuous. These limitations hinder the reconstruction of secular climate change in Mexico (Jauregui 1997) and increase the potential significance of highresolution proxy records.

In this paper, we provide varve chronologies for two maar lakes in the Valle de Santiago region in Central Mexico (Hoya La Alberca and Hoya Rincón de Parangueo), which are anchored using tephra layers and ${ }^{210} \mathrm{~Pb}$ dates. We use varve microfacies and element chemistry, determined continuously in ultrahigh resolution by micro X-ray fluorescence spectrometry, to reconstruct high-resolution records of environmental change that cover the period 1839 to 1973. These records provide an important perspective in an area of Mexico where environmental problems due to increasing urbanization, ground water exploitation, and environmental pollution are especially severe (Alcocer et al. 2000).

\section{Study sites}

Hoya La Alberca and Hoya Rincón de Parangueo, hereafter Alberca and Rincón, are located $1 \mathrm{~km}$ to the 
west and $6 \mathrm{~km}$ to the north-west of the city of Valle de Santiago in the state of Guanajuato (Fig. 1, Table 1). This part of the TMVB belongs to the MichoacánGuanajuato volcanic field. Both maars are of phreatomagmatic origin (Ordoñez 1906; Uribe-Cifuentes and Urrutia-Fucugauchi 1999). Potassium-Argon dates reported by Murphy (1986) indicate ages of $400 \mathrm{kyr}$ BP for Rincón and 73 kyr BP for Alberca. The Rincón crater is more than twice as large as the Alberca crater (Table 1). The local bedrock consists primarily of basaltic lava flows (Murphy 1986). Hornblende andesites at Alberca contain titanomagnetite in groundmass
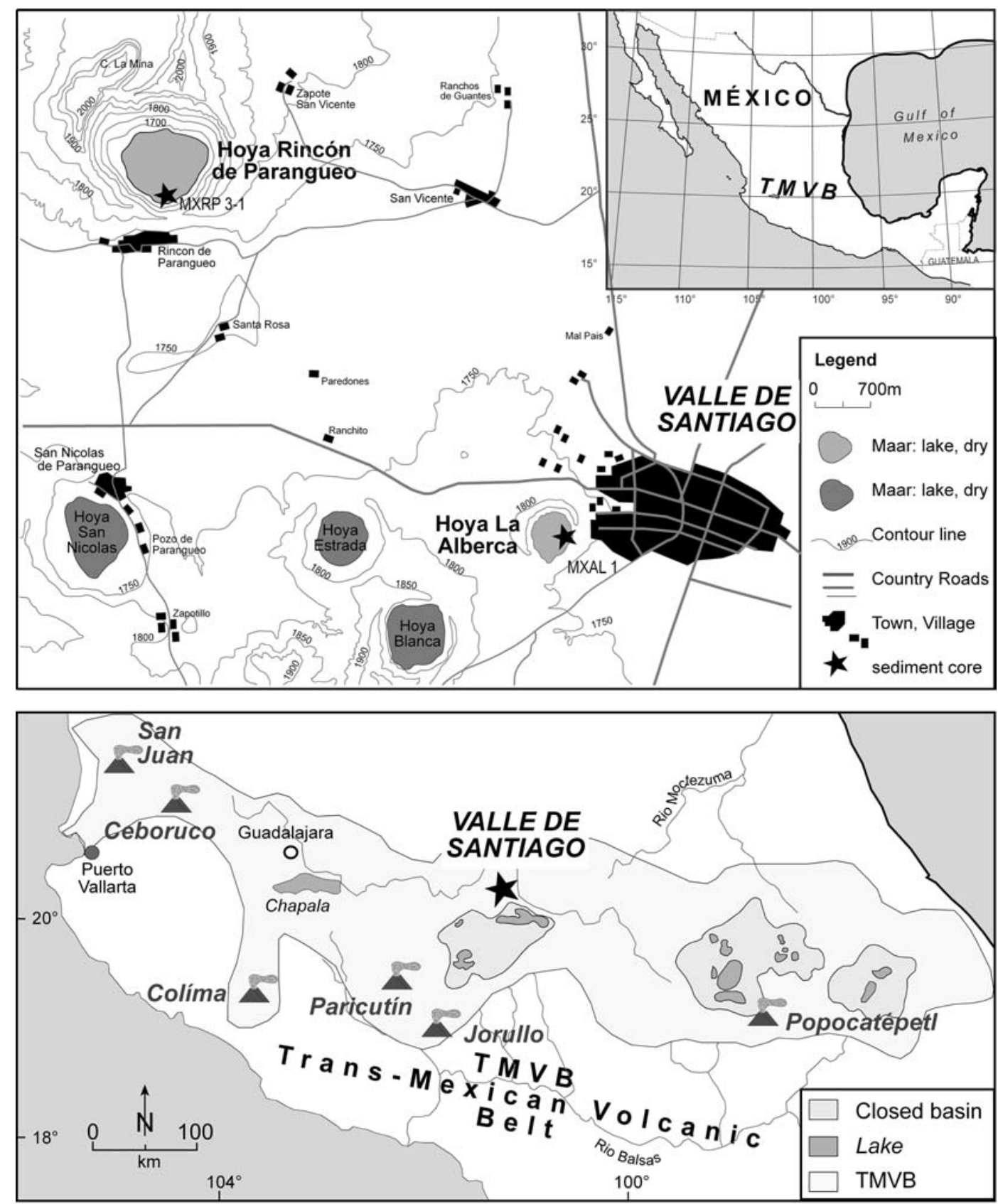

Fig. 1 Geographic setting of the Valle the Santiago: coring positions at Hoya La Alberca and Hoya Rincón de Parangueo (respective asterisks), geographic setting within the Trans-Mexican Volcanic Belt, and in relation to the temporally relevant volcanoes 
Table 1 Geographic setting, morphometric variables, and limnological data from Green (1986)

\begin{tabular}{lll}
\hline Variable & Hoya La Alberca & Hoya Rincón de Parangueo \\
\hline Coordinates & $20^{\circ} 23.35^{\prime} \mathrm{N} ; 101^{\circ} 12.1^{\prime} \mathrm{W}$ & $20^{\circ} 25^{\prime} \mathrm{N} ; 101^{\circ} 15^{\prime} \mathrm{W}$ \\
Altitude & $1,690 \mathrm{~m}$ a.s.l. & $1,700 \mathrm{~m}$ a.s.l. \\
Crater diameter & $1.2-1.3 \mathrm{~km}$ & $3.0-3.5 \mathrm{~km}$ \\
Crater wall height & $50-60 \mathrm{~m}$ & $\mathrm{~S} 90 \mathrm{~m}, \mathrm{~N}-\mathrm{NW} 200 \mathrm{~m}$ \\
Conductivity $20^{\circ} \mathrm{C}$ & $2.3 \mathrm{mS} \mathrm{cm}{ }^{-1}$ & $25 \mathrm{mS} \mathrm{cm}$ \\
Water color & Episodically reddish & dark green \\
Phytoplankton & Filamentous blue-green Oscillatoria sp. Spirulina sp., rarely Anabaena sp. \\
\hline
\end{tabular}

and plagioclase crystals (Hasenaka and Carmichael 1987).

The lakes that until recently occupied the maars were fed by an aquifer whose waters in large part derive from the Rio Lerma (Alcocer and Escobar 1996). Since the 1970s groundwater over-exploitation for irrigation agriculture and urban use has caused the water table to drop precipitously, e.g. $5 \mathrm{~m}$ between 1989 and 1992 (Alcocer and Escobar 1996; Alcocer et al. 2000).

In 1970 the lake level at Alberca was $15 \mathrm{~m}$ below the tuff ring (Fig. 2), indicating a maximum water depth of about $50 \mathrm{~m}$ (see also Green 1986). During the 1970s the water level began to drop. In 1997 we recorded a maximum depth of $8 \mathrm{~m}$, and in the summer of 2001 less than $1 \mathrm{~m}$. By January 2006 the lake had dried out completely. A sequence of aerial photographs documenting the progressive desiccation of the lake is shown as Fig. 2. The history of desiccation at Rincón is similar to that at Alberca. In 1979 Brown (1984) reported a water depth of $50 \mathrm{~m}$, and in 2006 we observed that the lake was less than 1 $\mathrm{m}$ deep. It is surrounded by the former littoral marl reef.

Limnological information regarding the two lakes is sparse. Orozco and Madinaveitia (1941) reported the dominant salts in Alberca as follows: $\mathrm{NaH}$ $\mathrm{CO}_{3}>\mathrm{NaCl}>\mathrm{Na}_{2} \mathrm{SO}_{4}$. They attributed them to the presence of $\mathrm{H}_{2} \mathrm{~S}$ and $\mathrm{CO}_{2}$ and the leaching of $\mathrm{Cl}^{-}$from volcanic rocks. Green (1986) presented
Fig. 2 Air photographs of Hoya La Alberca

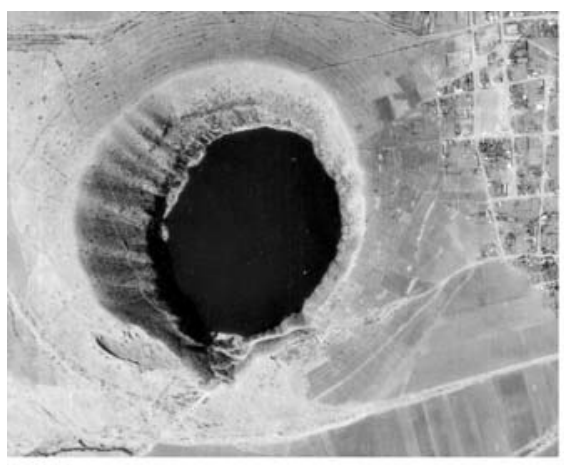

$$
1970
$$

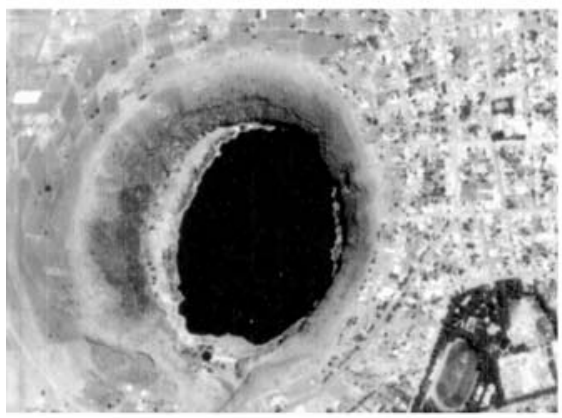

June 1993

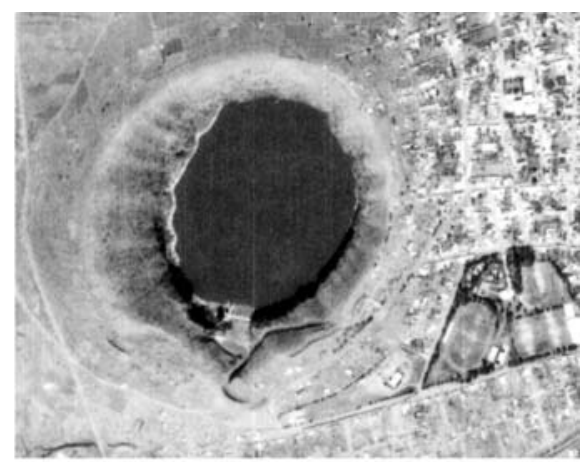

February 1984

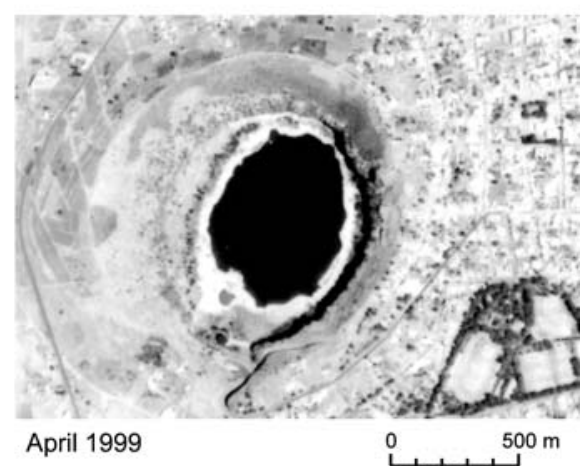


conductivity data taken in 1981, which show a tenfold higher electrical conductivity of Rincón compared to Alberca (Table 1). Besides precipitation, both lakes are fed by groundwater (see above). Springs existed within the craters in the recent past, but according to local reports, all have now dried up (Alcocer et al. 2000).

The vegetation within the Alberca maar has been heavily disturbed by wood cutting and grazing. Common trees are Mesquite (Prosopis laevigata) and the introduced Peruvian Pepper Tree (Schinus molle). The upper slopes of the crater are mostly covered by shrubby members of the Asteraceae (Parthenium, Brickellia, and Montanoa) and Leguminosae (Mimosa and Acacia). Prickly Pear Cactus (Opuntia), Yucca and Agave are also common. The Rincón maar is less accessible than Alberca and slopes of the crater are still covered by a floristically rich remnant of subtropical forest that includes species of Bursera, Heliocarpus, Euphorbia and Conzattia. Several members of the Cactaceae (Opuntia and Saguaro) are common locally (Aguilera Gómez 1991). Mesquites are common in heavily grazed areas and a small area on the northwest side of the remnant lake has been cleared for cultivation.

The present climate of the Valle de Santiago is marginal for rain-fed agriculture. Long-term (19611990) monthly means (data from Servicio Meteorologico Nacional) indicate a mean annual precipitation of $679 \mathrm{~mm}$, of which $90 \%$ occurs between May and October. Monthly means range from $6 \mathrm{~mm}$ in February to $156 \mathrm{~mm}$ in July. Inter-annual rainfall variability is high with extremes of $336 \mathrm{~mm}$ and $1,193 \mathrm{~mm}$ during the full instrumental period 19222003, which has many gaps between 1930 and 1944 and in the early 1980s. Potential evaporation is highest between March and May, when monthly mean values exceed $200 \mathrm{~mm}$. The mean annual temperature is $19^{\circ} \mathrm{C}$ with monthly means ranging from $14^{\circ} \mathrm{C}$ in January to $23^{\circ} \mathrm{C}$ in May.

\section{Field and laboratory methods}

\section{Coring}

We took the Alberca core (MXAL1) in March 2003, when a very shallow $(<0.5 \mathrm{~m})$ sheet of water still occupied the lowest part of the lake floor. The core was recovered on the eastern edge of the lake bed (asterisk in Fig. 1). The core was taken by manually pushing an 8 -cm-diameter plastic tube into the sediment. The upper $15 \mathrm{~cm}$ of sediment had clearly washed in since the lowering of the lake had exposed the core site and was therefore discarded. The lake sediment sequence recovered was $40.5 \mathrm{~cm}$ long (Fig. 3a). The sediments consist of two alternating types of laminae: dark brown with grey or red shading and light beige to olive; the former are primarily silt and clay with organic material and the latter micritic carbonatic mud. The lighter laminae are partly interrupted in the bedding plane. Graded clastic layers of dark grey color occur irregularly. Some of them appear brownish and include a higher portion of organic detritus.

We took the Rincón core (MXRP3) in 2001 from the edge of the remnant lake (asterisk in Fig. 1). At the time, the water was less than $1 \mathrm{~m}$ deep, but the unconsolidated nature of the sediments made it impossible to core from the lake itself. The coring device was a 5-m-long plastic tube fitted with a hammering head and a piston with an attached steel cable. The tube diameter was $8 \mathrm{~cm}$. We used scaffolding so that the tube could be sledge hammered into the sediment. The tube and enclosed sediment were raised with a block and tackle. The recovered section MXRP3-1 was $1.06 \mathrm{~m}$ long, of which the upper $45 \mathrm{~cm}$ is a slump deposit. In this paper we only report on the finely laminated section between 57.6 and $75 \mathrm{~cm}$ (Fig. 3b). Beige laminae are composed of micritic carbonatic mud. They alternate with dark brown laminae composed of clay and silt with organic detritus. Intercalated are prominent, almost black layers that consist primarily of silt and fine sand. In a parallel core, UCB 2004 (total recovery $418 \mathrm{~cm}$ ), the top $86 \mathrm{~cm}$ is a slump deposit and the finely laminated sediment below it extends from $104 \mathrm{~cm}$ to $155 \mathrm{~cm}$.

Sampling and preparation (Varves and Tephra)

A series of overlapping thin sections was prepared from each core. Sediment blocks $(100 \times 20 \times$ $20 \mathrm{~mm}$ ) were shock-frozen, freeze-dried, impregnated with epoxy resin, sectioned with a microtome, and ground to a thickness of approximately $40 \mu \mathrm{m}$. A Zeiss Axioskop 2 plus microscope was then used to measure the thickness of laminae and to locate tephras. Measurements were made with normal and polarized light 
Fig. 3 Photographs of the top of the studied core sections (a) Hoya la Alberca and (b) Hoya Rincón de Parangueo, in relation to the core stratigraphy of the total sections MXAL1 and MXRP3-1, and positions of important features and tephra layers

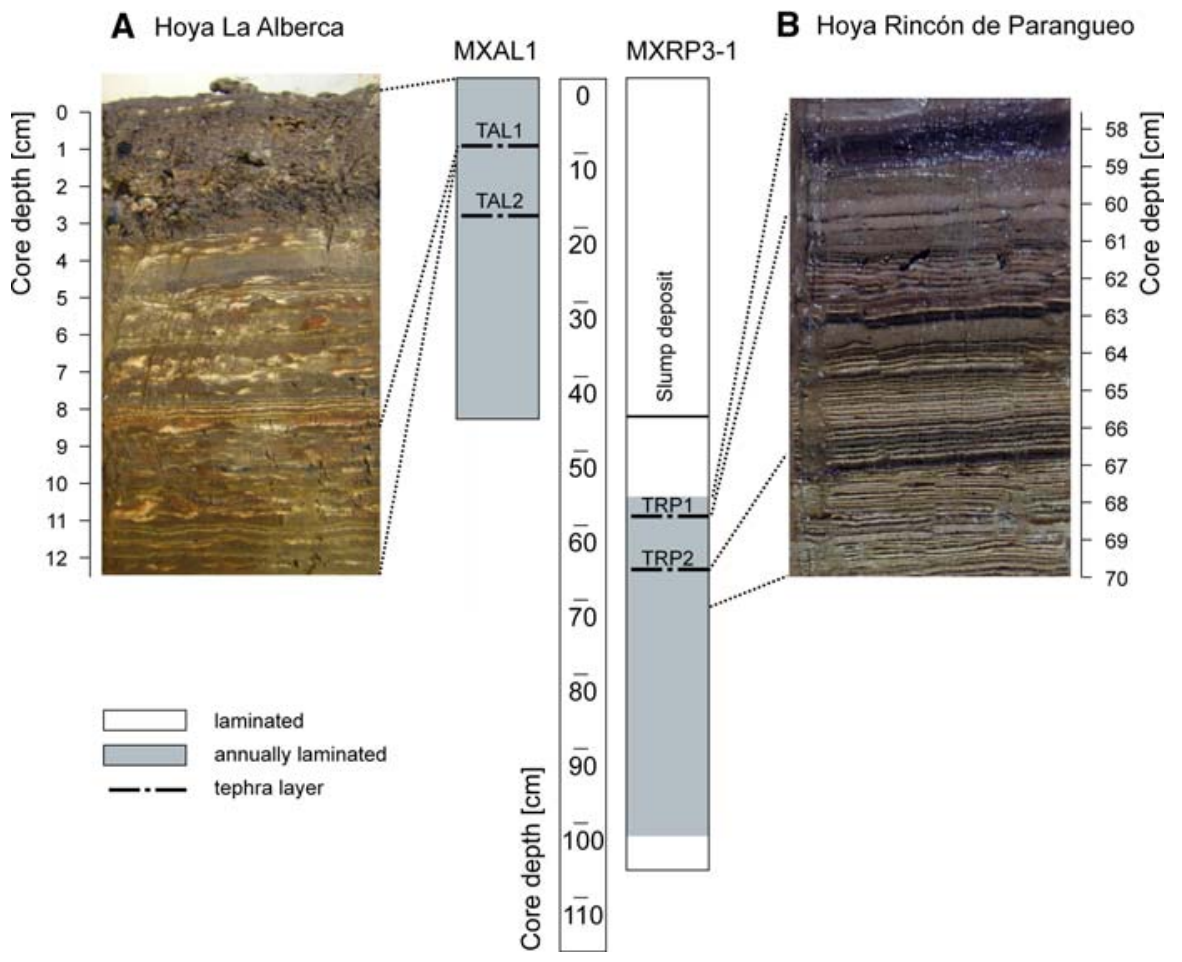

at magnifications ranging between $25 \times$ and $630 \times$. In order to clarify seasonality and formation of the laminae, we took micro-samples from selected light carbonate and dark detrital layers. Graded laminae and aggregated carbonate crystals were avoided.

Two distinct tephra layers were observed in both studied sections. The petrographic features of the distal tephras were obtained from large-scale thin sections. Ash samples from proximal sites of the Jorullo and Paricutín cinder cones were analysed for comparison. All tephra samples were carefully cleaned with $30 \% \mathrm{H}_{2} \mathrm{O}_{2}$ to remove the organic matter and surface coatings. The silt-sand fraction was dried and sieved with $200-\mu \mathrm{m}$-mesh polyester sieves. The finer fraction was used for the preparation of polished thin sections.

\section{Tephra geochemistry}

The major-element chemistry of the tephras was determined on single glass shards by Electron probe microanalysis (EPMA) at GFZ Potsdam using a Cameca SX-100 electron probe (WDS). Conditions during measurements were $15 \mathrm{kV}$ accelerating voltage, $20 \mathrm{~mA}$ beam current, and $15 \mu \mathrm{m}$ beam size. Peak counting times were $10 \mathrm{~s}$ for $\mathrm{Na}$, measured first, and $20 \mathrm{~s}$ for all other elements. Instrumental calibration used inter-laboratory natural mineral and glass reference materials (Lipari obsidian) (Hunt and Hill 1996; Brauer et al. 2007). Analyses were recalculated to $100 \%$ on a $\mathrm{H}_{2} \mathrm{O}$ - and $\mathrm{CO}_{2}$ - free basis, and plotted in the Total-Alkali-Silica diagram for rock classification (Le Bas et al. 1986).

\section{Sediment analyses}

The element chemistry of the cores was studied on the same embedded sediment slabs from which the thin sections were produced. Micro X-ray fluorescence $(\mu \mathrm{XRF})$ measurements were made at $40 \mathrm{kV}$ and $250 \mu \mathrm{A}$ with an EAGLE III XL spectrometer equipped with a Rhodium tube. Step size and spot size were 40 and $50 \mu \mathrm{m}$ for the Alberca samples and 100 and $123 \mu \mathrm{m}$ for the Rincón samples. In order to compare results of the microscopic thin section analysis and the $\mu \mathrm{XRF}$ data, we used the varve chronology to assign an age estimate to each measuring step of the element scanning. A point-by-point comparison of the results of varve analysis and $\mu \mathrm{XRF}$ scanning is difficult because the measuring points of the scanning are in discrete steps as opposed to a continuous laminae-oriented analysis by light microscopy. 
For stable isotope analysis, dried samples from carbonate laminae were weighed in the range of 0.01 to $0.05 \mathrm{mg}$. The stable isotope values were determined using an automated carbonate extraction system (KIEL IV) interfaced with a MAT 253 IRMS (ThermoFisher Scientific) at the GeoforschungsZentrum, Potsdam. Isotopic ratios are given in the delta notation relative to the VPDB (Vienna Peedee Belemnite) where: $\delta$ $\left.(\% 0)=\left[\left(R_{\text {sample }}-R_{\text {standard }}\right) / R_{\text {standard }}\right)\right] \times 1000$. Isotopic measurements are calibrated to NBS19 (limestone) and NBS18 (carbonatite) and an internal laboratory standard $\mathrm{C} 1$ (marble). The isotopic precision is better than $0.03 \%$ for $\delta^{13} \mathrm{C}$ and $0.06 \%$ for $\delta^{18} \mathrm{O}$ measurements.

For total organic carbon (TOC) and $\delta^{13} \mathrm{C}$ determination of organic/detrital laminae, ca. $3 \mathrm{mg}$ of dried sample were weighed in Ag-capsules, treated with $20 \% \mathrm{HCl}$, heated for $3 \mathrm{~h}$ at $75^{\circ} \mathrm{C}$, and finally wrapped in Ag-capsules. Analysis of decalcified samples was performed with a Carlo Erba NC 2500 elemental analyzer coupled with a DELTAplusXL mass spectrometer via a ConFlow III interface (ThermoFisher Scientific, Bremen). The calibration was performed using a certified elemental standard (Urea) and an isotopic standard (CH-7) and checked with a soil reference sample (Boden2). The reproducibility for replicate analyses is $0.2 \%$ for carbon and $0.15 \%$ for $\delta^{13} \mathrm{C}$, respectively.

$\mathrm{X}$-ray diffraction analyses (RDA) were carried out using a Siemens D5000 $\theta-2 \theta$ powder diffractometer with $\mathrm{Cu} \mathrm{K} \alpha$ radiation, automatic divergent and antiscatter slits and a secondary graphite monochromator with a scintillation counter. The diffraction data were recorded from 4 to $75^{\circ} 2 \theta$ with a step width of $0.02^{\circ}$ and a counting time of $4 \mathrm{~s}$ per step. The generator settings were $40 \mathrm{KV}$ and $30 \mathrm{~mA}$. The Rietveld algorithm BGMN was used for quantitative analysis (Bergmann et al. 1998).

Ten sediment samples $\left(1 \mathrm{~cm}^{3}\right)$ from the upper section of the UCB 2004 core were submitted to Flett Research (Canada) for ${ }^{210} \mathrm{~Pb}$ analysis. Prior to submission, samples were oven-dried at $100^{\circ} \mathrm{C}$ for $24 \mathrm{~h}$ to determine dry mass per unit wet volume. ${ }^{210} \mathrm{~Pb}$ activities were determined by distillation of ${ }^{210} \mathrm{Po}$, the granddaughter of ${ }^{210} \mathrm{~Pb}$, from the sediments with hydrochloric acid, digestion in hot concentrated nitric acid, plating onto silver disks, and alpha counting with a Ortec "Octec" alpha spectrometer. The methodology is based upon that of Eakins and Morrison (1978). A chronology was established for the section of the core below the slump with the CRS model developed by Appleby and Oldfield (1978).

Statistical analyses

The $\mu \mathrm{XRF}$ results and the varve sublaminae thicknesses were analyzed statistically to identify the main gradients of variability in the data set. Detrended correspondence analysis (DCA) was used to establish whether linear or unimodal ordination methods were suitable (Hill and Gauch 1980). DCA was applied to calculate the length of gradient expressed in the response variable in standard deviation units (SD) of the variable under consideration. Linear methods (e.g. principal components analysis, PCA) are used when the gradient length is short $(<3 \mathrm{SD})$, whereas non-linear methods (e.g. correspondence analysis, CA) are preferred if the gradient length exceeds $3 \mathrm{SD}$ (Legendre and Legendre 1998). The ordinations were performed with CANOCO 4.5 (Ter Braak and Smilauer 2002).

We calculated annual means of the element counts by dividing, for each element, the sum of the counts of all measuring steps that belong to 1 year by the respective number of steps.

\section{Results and discussion}

Tephra analysis

Two well preserved distal tephras, TAL1 and TAL2 (Fig. 3a), were detected in the Alberca core and used for primary geochemical correlation with tephras from known sources. Another two ashes TRP1 and TRP2 (Fig. 3b), with similar characteristics, were found in the Rincón core. Their chemical classification was difficult because of the strongly altered volcanic glasses, presumably due to the high alkalinity of the lake water.

Tephra TAL1 is a 1-mm-thick ash layer at $8.7 \mathrm{~cm}$ depth. It is fine-grained, double-layered, and brown in color. Its juvenile phase is characterized by brown blocky glass shards rich in micro-crystals and medium-K andesitic in composition. Silica $\left(\mathrm{SiO}_{2}\right)$ abundances are high (57.5-59.8\%). The ash reveals only a minor phase of lithic components (tachylites) and phenocrysts: plagioclase, clinopyroxene, orthopyroxene and amphibole. Tephra TAL1 most likely corresponds to tephra TRP1 (at $58.8 \mathrm{~cm}$ core depth) 
because of its identical features like thickness $(1 \mathrm{~mm})$, sediment texture, maximum grain sizes $(<150 \mu \mathrm{m})$ and mineral/lithic assemblage. The major element chemical composition of one single glass shard in TRP1 also indicates a correlation between these two ashes (Table 2).

Tephra TAL2 is a 2.5-mm-thick, silt-sized ash layer at $17.5 \mathrm{~cm}$ depth. Its major juvenile components are brown, non-vesicular glass shards, rich in micro-crystals, and rhyolitic in composition. A second glass phase comprises colourless vesicular blocky shards of high-K basaltic andesitic composition with high variations in $\mathrm{TiO}_{2}(0.7-3.0 \mathrm{wt} \%)$ and $\mathrm{FeO}(6.7-10.4 \mathrm{wt} \%$ ) values (Table 2). Phenocrysts in tephra TAL2 are abundant and include plagioclase, clinopyroxene, orthopyroxene, amphibole, olivine and $\mathrm{Fe}-\mathrm{Ti}$ oxides. Lavic rocks, altered tuffs, quartz clasts and tachylites form the comprehensive lithic assemblage. Tephra TAL2 shows strong similarities to tephra TRP2 with regard to its stratigraphic position less than $10 \mathrm{~cm}$ below the TAL1/TRP1 tephras, sediment structure, thickness $(2 \mathrm{~mm})$, maximum grain sizes $(<300 \mu \mathrm{m})$ and mineral/lithic composition. Geochemical correlation is hindered by the extreme alteration of volcanic glass and therefore, lack of major element data of tephra TRP2.

Origin of the tephras

We used major-element glass chemistry and mineralogy, as well as their stratigraphic positions in the sediment sequences, to correlate the Alberca/Rincón distal tephras with proximal ashes of historical eruptions reported in Mexico and Central America.

In the Central American region, several highmagnitude volcanic eruptions occurred during the period of interest (AD 1800-2003). In October 1902 the eruption of Santa Maria or Santiaguito (Guatemala) was the second largest $(\mathrm{VEI}=6)$ volcanic eruption globally in the twentieth century. Ash fall was noticed as far away as Colima, Mexico, $1,400 \mathrm{~km} \mathrm{NW}$ of the source, and even in the city of San Francisco (California) 3 months later (Williams and Self 1983). The erupted white pumices, typical of Guatemalan volcanoes: bimodal dacites and basaltic andesites (Rose 1987), do not match the chemical composition of the Alberca/Rincón tephras (Fig. 4). A large (VEI 5) eruption of Cosigüina volcano in
Nicaragua in 1835 (Self et al. 1989), also differs in chemical composition (dominantly andesitic).

Considering the central location of the Valle de Santiago maars in the TMVB and the prevailing wind directions, recently active Mexican volcanoes (Fig. 1) represent the most likely sources of the Alberca/Rincón tephras. In the eastern part of the TMVB, Popocatépetl and El Chichón (Chiapas, SE Mexico) are possible candidates. In 1982, El Chichón generated a Plinian eruption, producing tephra of dacitic-andesitic composition (Luhr et al. 1984) (Fig. 4). Popocatépetl generated its last Plinian eruption in AD 800, and only smallvolume eruptions occurred in the study period (highest VEI of 3 in 1996; Siebert and Simkin 2002). A smallvolume eruption of Orizaba volcano took place in 1846. Ash falls of both El Chichón and Popocatépetl are mainly dispersed to the $\mathrm{E}$ and SSW, respectively (Varekamp et al. 1984; Robin and Boudal 1987), and are therefore unlikely to have reached the Valle de Santiago region.

In the western TMVB, several volcanoes including Ceboruco, Fuego de Colima, and others in the Michoacán-Guanajuato volcanic field have been active during historical time. Ceboruco erupted small volumes of tephra in 1870, which differs in composition from the Alberca/Rincón tephras (Fig. 4). Other eruption reports are uncertain, such as an Indian legend of a solar eclipse in the eleventh century during which seven volcanoes in the Valle de Santiago erupted, covering the area with ash and lava (Yarza de De la Torre 1971). Also, an eruption reported at San Juan volcano in 1859 is considered uncertain (Luhr 2000). Fuego de Colima, the southernmost active volcano of the Colima volcanic complex, $260 \mathrm{~km} \mathrm{SW}$ of Valle de Santiago, is the most active volcano of Mexico in historic time. The latest Plinian style eruptions took place in 1818 and 1913 (De la Cruz-Reyna 1993; González et al. 2002; Saucedo et al. 2005). Sub-Plinian eruptions with heavy ash fall were reported in 1886-1890, 1903 and 1908 (De la Cruz-Reyna 1993). The cataclysmic eruption in January 1913 is considered to be Colima's largest, featuring a VEI of 4 and generating ash fall that was reported $400 \mathrm{~km} \mathrm{NE}$ and $725 \mathrm{~km} \mathrm{NNE}$ of the source (Waitz 1915; González et al. 2002).

The Michoacán-Guanajuato volcanic field is characterized by dense monogenetic activity of more than 1,000 cinder cones, rare shield volcanoes, and stratovolcanoes (Hasenaka and Carmichael 1985). 


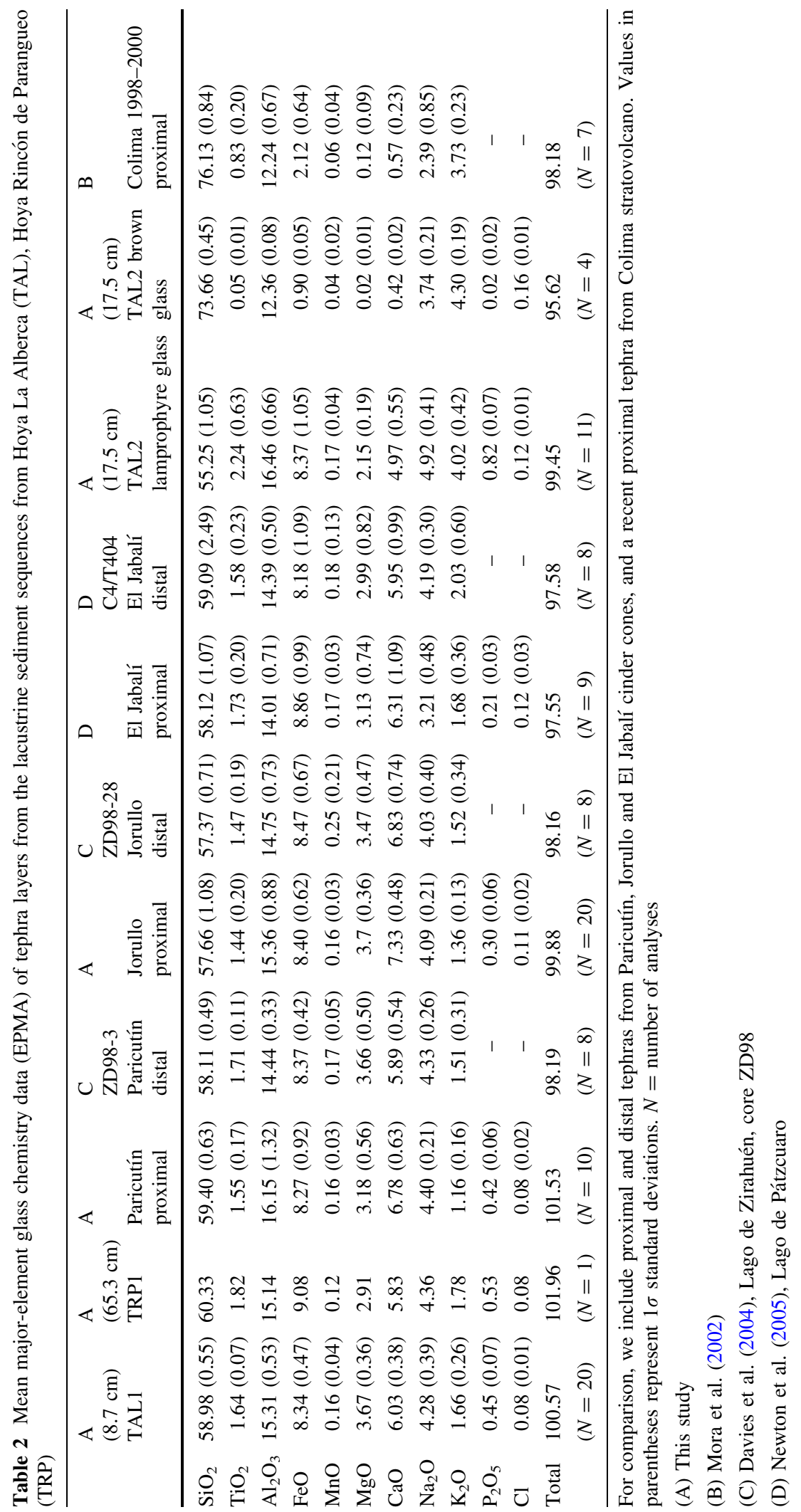




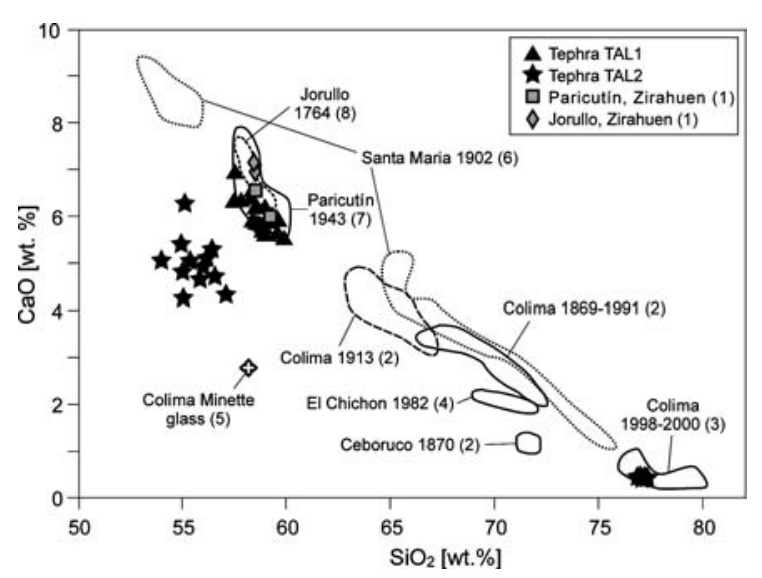

Fig. 4 Chemical plot $\mathrm{SiO}_{2}$ vs. $\mathrm{CaO}$ for discriminating distal tephras of the Alberca and Rincón sediment records from widespread tephra deposits of Central American volcanoes. Data from: (1) Davies et al. (2004), EPMA glass shards, (2) Luhr (1992), EPMA matrix glass; (3) Mora et al. (2002), EPMA groundmass; (4) Luhr et al. (1984), EPMA matrix glass; (5) Luhr and Kyser (1989), EPMA glass shards; (6) Rose (1987), XRF pumice; (7) this study, EPMA glass shards, EMPA; Luhr (2001), EPMA matrix glass; (8) this study, EPMA glass shards; All data are normalized on an anhydrous basis

According to $\mathrm{K} / \mathrm{Ar}$ and radiocarbon dates, approximately 16 cinder cones formed during the Holocene; the youngest erupted at $3830 \pm 150{ }^{14} \mathrm{C} \mathrm{yr} \mathrm{BP}(\mathrm{El}$ Jabalí). During historic times, Jorullo (AD 17591774) and Paricutín (AD 1943-1952) generated the largest amounts of basaltic andesitic ash fall in 1764 and 1943, respectively (Gadow 1930; Wilcox 1954; Luhr and Carmichael 1985). Distal tephras of both eruptions were distributed $200 \mathrm{~km}$ to the NE, as far away as Querétaro (Moreno 1986), and up to $320 \mathrm{~km}$ to the E, to México City (Fries 1953). These tephras have been identified in the sediments of the Zirahuén and Pátzcuaro lakes, SW of Valle de Santiago (Davies et al. 2004; Newton et al. 2005).

The chemical, petrographic and stratigraphic analyses of the distal tephras found in the lacustrine sediment sequences of Alberca (TAL1 and TAL2) and Rincón (TRP1 and TRP2) indicate that their sources are explosive eruptions of the nearby MichoacánGuanajuato volcanic field and the Fuego de Colima stratovolcano. Though geochemical discrimination of Michoacán tephras is difficult (Fig. 4, Table 2), we can exclude as an origin of tephras TAL1 and TRP1 mid- to late Holocene eruptions such as El Jabalí cinder cone, based on chronologic (see below) and stratigraphic (lack of hiatus) evidence, and suggest instead a correlation with one of the historic eruptions of Jorullo or Paricutín. Because of slightly higher $\mathrm{SiO}_{2}$ and lower $\mathrm{FeO}$ and $\mathrm{CaO}$ concentrations of glass shards, we propose a correlation of tephras TAL1 and TRP1 with the initial explosive phase of the Paricutín eruption in 1943/1944.

The stratigraphic positions of tephra layers TAL2 and TRP2, 30 light/dark laminae couplets below TAL1 and TRP1, together with the thickness, grain size and lithological characteristics of the tephra, suggests the Colima 1913 eruption as their likely origin. Confirmation on the basis of chemical data is difficult because the rhyolitic and basaltic andesitic glass composition of TAL2 differs from two single scoria samples from proximal 1913 Colima deposits, which are of andesitic composition (Luhr 1992) (Fig. 4). These scoria samples may, however, not be representative for the entire 1913 tephra fallout sequence, and tephra of this eruption has not yet been analysed at distal sites. The recent 1998-2000 Colima tephras, for instance, reveal an additional rhyolitic matrix glass (Mora et al. 2002) that resembles the TAL2 tephra (Fig. 4, Table 2). The basaltic andesitic glass phase of TAL2, in turn, is typical for Colima lamprophyric composition (Fig. 4). Although lamprophyres (minettes) were not erupted in historic time, related components might be present as accidental lithics in younger tephra products. The occurrence of a distal, and highly vesicular, but unfortunately unanalysed tephra, in a similar stratigraphic position underneath the Paricutín tephra in Zirahuen cores (Newton et al. 2005), supports our classification of TAL2 and TRP2 as tephras of the Colima 1913 eruption.

Laminae properties (microscopic, mineralogy, isotope ratios) and formation

Microscopic inspection of the thin sections indicates that the sequence of laminae is similar in both sediment profiles. The typical arrangement is shown in Fig. 5. The light carbonate laminae consist of densely packed carbonate crystals 2 to $5 \mu \mathrm{m}$ long. No grading from large to smaller crystals is observed. Components of the dark detrital laminae are clastic detritus (silt and clay) and fine organic detritus in changing proportions. Large littoral diatoms of the genera Gomphonema, Cymbella, Epithemia, and 
Nitzschia, and ostracod shells, occur rarely. At the base and top of the dark laminae, yellow-green or red-brown organic-rich muds occur, either concentrated in laminae or disseminated in the dark lamina. The coloration and plant tissue content, at least in the youngest sediments, suggest they are of algal origin, possibly Oscillatoria or Spirulina (see Green 1986).

Intercalated with this typical sequence of laminae are layers that are graded, as is typical for turbidites. Here they grade from fine sand-sized particles to clay-sized particles at the top. They contain remains of plant macrofossils, clastics, and aggregated carbonate crystals up to $50 \mu \mathrm{m}$ in diameter. Such aggregates are also observed in part of the topmost dark laminae. Because of their homogeneous internal fabric and size, they may be fecal pellets (Freytet and Verrecchia 2002). A mechanical origin (Fahraeus et al. 1974), however, cannot be ruled out, as they occur exclusively in graded layers and dark laminae.

In the $\mu \mathrm{XRF}$ element scans (example sections in Fig. 6), the light carbonate laminae are characterized by peak values of calcium, while the dark detrital laminae contrast with high counts of titanium. In comparison, RDA resulted in higher contents of aragonite and hydromagnesite of the light laminae in Rincón, supplemented by monohydrocalcite in Alberca, while the dark detrital laminae show higher percentages of plagioclase and quartz accompanied by amorphous organic matter (Fig. 7). Detrital mineral portions are larger in Alberca. The occurrence of halite is unrelated to laminae formation (see below).
Alberca

(MXAL1)

Rincón

(MXRP3-1)

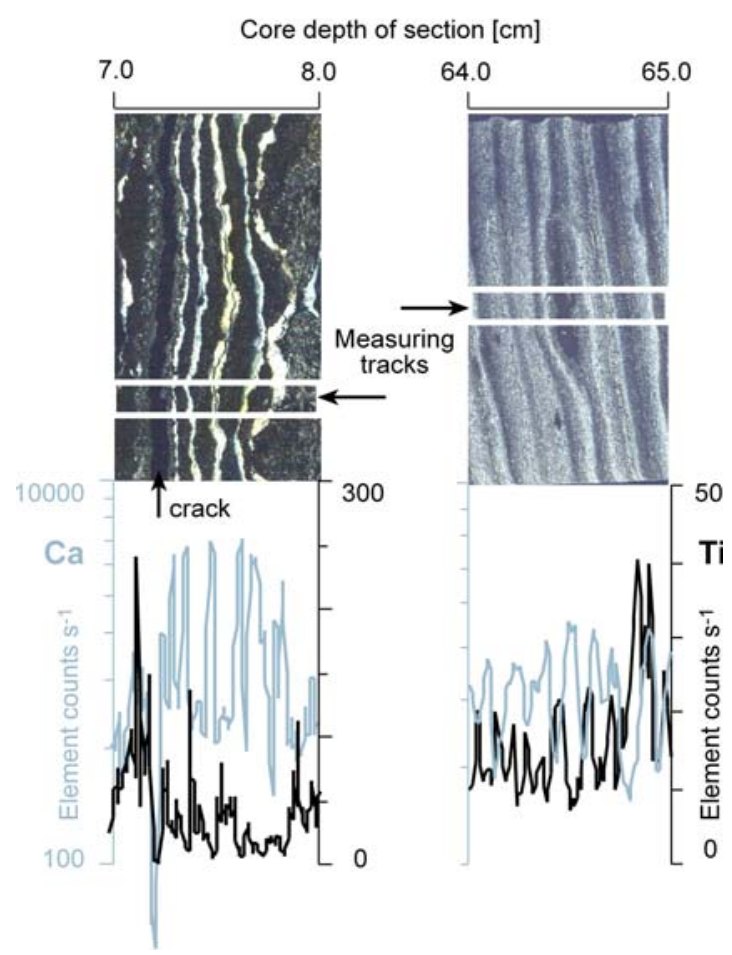

Fig. 6 Laminae classification according to their $\mathrm{Ca}$ and $\mathrm{Ti}$ counts plotted with the respective thin section images from the sequences from Alberca and Rincón

The isotope analyses of the carbonate laminae samples resulted in positive stable isotope ratios of both carbon and oxygen (Fig. 8). The range of the $\delta^{18} \mathrm{O}_{\text {carb }}$ is
Fig. 5 Schematic laminae succession (microfacies) compiled with monthly mean values of temperature, precipitation and evaporation (Station Valle de Santiago, longterm mean 1961-1990, Servicio

Meteorologica Nacional de México), $\mu$ XRF counts of $\mathrm{Ca}$ and $\mathrm{Ti}$, and the mineral composition of the laminae
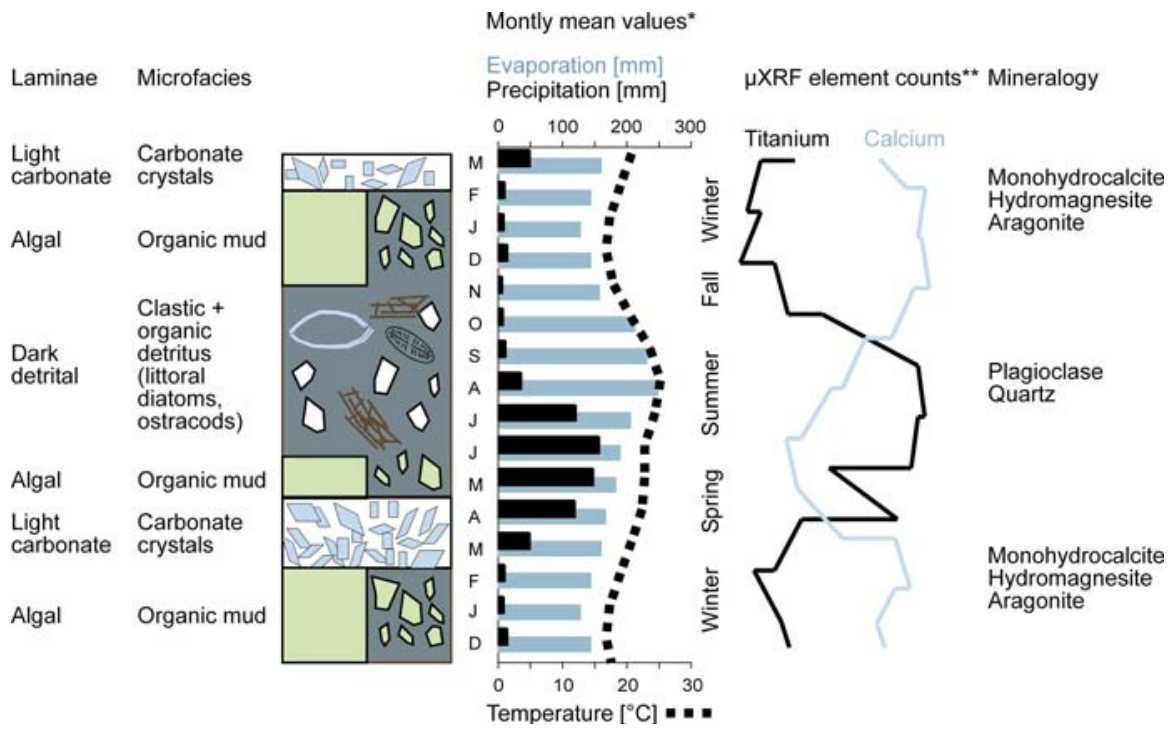

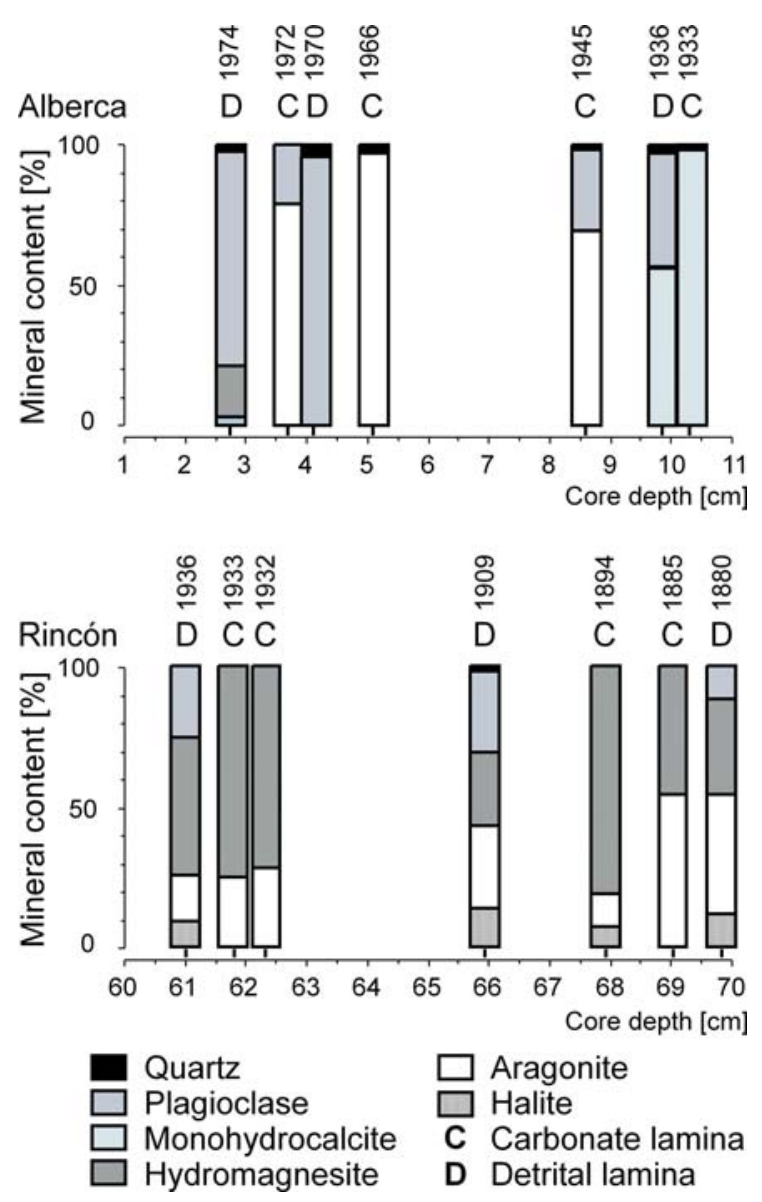

Fig. 7 Mineralogy of selected carbonate laminae (C) and detrital laminae (D) from RDA

narrower for Alberca $(+1.8$ to $+4.7 \%$ ) compared to Rincón $(+2.4$ to $+7.5 \%)$, while the $\delta^{13} \mathrm{C}_{\text {carb }}$ is clearly lower at Alberca $(+4.7$ to $+6.6 \%$ ) than at Rincón $(+12.2$ to $+16.3 \%$ ) (Fig. 8a). For the organic/detrital laminae, negative $\delta^{13} \mathrm{C}_{\text {org }}$ values were obtained. Similar to the isotope composition of the carbonate laminae, the $\delta^{13} \mathrm{C}_{\text {org }}$ values are lower at Alberca $(-24.4$ to $-21.9 \%$ ) than at Rincón $(-17.9$ to $-16.6 \%$ ) with a narrower range of TOC at Rincón (2.9 to $4.6 \mathrm{wt} \%$ ) compared to Alberca (1.7 to 9.7 wt\%) (Fig. 8b).

For the light carbonate laminae, the uniform, small crystals suggest rapid precipitation from the water column. Indications for the involvement of biological processes are the mineralogy of the laminae (hydromagnesite and monohydrocalcite; Coshell et al. 1998; Warthmann et al. 2000) and the postive $\delta^{13} \mathrm{C}_{\text {carb }}$ (McKenzie 1985). On the other hand, grading from larger to smaller crystals and typical shapes such as dumbells, footballs or microspheres, as observed for bio-induced precipitation (Teranes et al. 1999), were not found. Also, the uniform crystals may argue against more than one process being involved in their formation. The oxygen isotope values of the carbonates are enriched relative to the calculated modern mean annual $\delta^{18} \mathrm{O}$ of rainfall. For Zacapu, ca. $100 \mathrm{~km}$ to the SSW, the range for rainfall is -11 to $-8.2 \%$ (Leng et al. 2005). For the Valle de Santiago, we obtained a range of -11 to $-7.7 \%$ o for the period in which $90 \%$ of the annual rain falls (May to October) (http://wateriso.eas. purdue.edu/waterisotopes/pages/data_access/oipc.html ). Furthermore, the $+1.6 \%$ o $\delta^{18} \mathrm{O}$ and $-15.4 \%$ o $\delta \mathrm{D}$ given for Alberca spring surface water indicate evaporation (Leng et al. 2005). We consequently attribute the formation of the carbonate laminae primarily to evaporation, although the influence of algal photosynthesis cannot be ruled out (Leng et al. 2006; Li and Ku 1997; Valero-Garcés et al. 1995).

Seasonality of the laminae and varve formation

Reports on seasonal plankton succession in Mexican lakes are scarce, but some exist, e.g. Lake Pátzcuaro: Bernal-Brooks et al. (2003); Lake Chapala: Lind et al. (1992); Lake Alchichica: Oliva et al. (2001). Using this information, we deduced the correspondence between the observed sequence and characteristics of laminae and the annual climate cycle (Fig. 5). During the second half of the dry season, from March to mid May, increased evaporation concentrates dissolved solids in the epilimnion, as exemplified by the relation of $\mathrm{NaCl}$ concentration in lake Alberca $\left(0.83 \mathrm{~g} \mathrm{l}^{-1}\right)$ to that in its springs (0.043 $\mathrm{g}^{-1}$ ) (Orozco and Madinaveitia 1941). For Rincón, the heavier isotope values (Fig. 8a) and its tenfold higher conductivity suggest this contrast to be even greater. Calcium and strontium are eventually precipitated with carbonate crystals (Valero-Garcés and Kelts 1995). With the onset of the rainy season in May/June, spring algal blooms are supported by increasing temperatures and nutrients washed into the lake (Lind et al. 1992). The blooms may induce carbonate precipitation that adds to the light lamina. Summer rainfall causes surface runoff that transports clastic and organic detritus into the lake. It also resuspends sediments in the littoral, the source for the large diatoms. Phytoplankton is suppressed through rainfall directly on the lake surface, turbidity, and nutrient dilution (Bernal-Brooks et al. 2003; 
Fig. 8 Characteristics of carbonate (a) and detrital/ organic (b) laminae: TOC, Carbon and oxygen isotope ratios
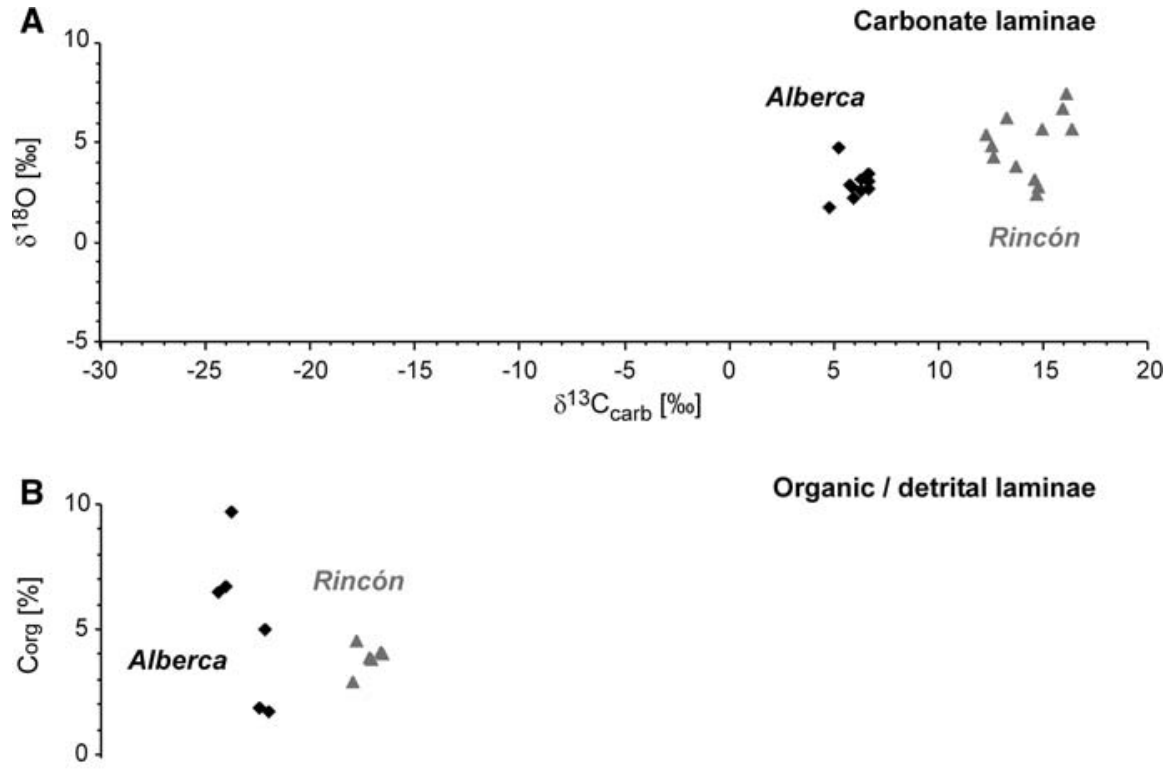

Organic / detrital laminae

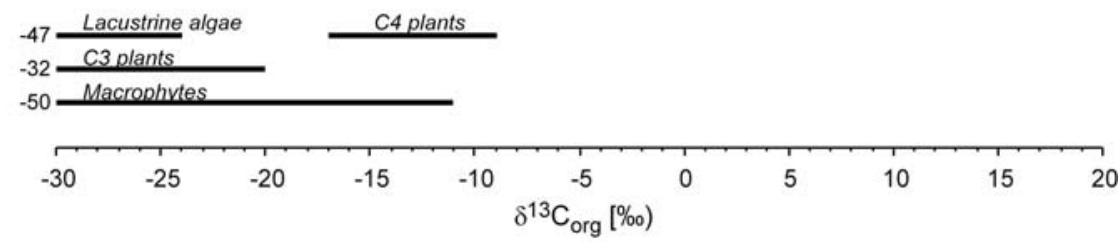

(Carbon isotope ranges according to Meyers and Lalier-Vergés, 1999; Leng et al., 2005)
Hernandez-Aviles and Bernal-Brooks 2001; Oliva et al. 2001). With decreasing rainfall and temperatures in fall, the water column mixes and a second bloom of algae occurs, probably benefiting from recycled nutrients and improved light conditions after reduction of the suspended matter. The bloom persists until February/March, when nutrients become limiting (BernalBrooks et al. 2003; Oliva et al. 2001).

In each case, the laminae consisting of carbonate, detrital material or algal remains together make up the annual layer, expressed as varves with respective thicknesses. The graded detrital layers (turbidites) are most likely attributable to exceptionally strong rainfall events that contribute terrestrial material to the lake. But slumping cannot be excluded as an origin for these deposits. Consequently, we have excluded them from the varve thickness. The thickness distribution data of the varve sublaminae are listed in Table 3.

\section{Chronology}

The varve chronologies from both Alberca and Rincón are anchored by the tephras attributed to the
Colima 1913 eruption and the Paricutín eruption of 1943 and ${ }^{210} \mathrm{~Pb}$ dates (Fig. 9, Table 4). Lead-210 analyses of the parallel Rincón core UCB 2004 are used, based on an exact sample classification permitted by the distinct sediment lamination and equal sedimentation rates of core MXRP3-1. The ${ }^{210} \mathrm{~Pb}$ ages, calculated applying the CRS model (Appleby and Oldfield 1978), support the tephra ages and the varve chronology. The time marker is 1985.8 at the bottom of the slump deposit (Fig. 3b, Table 4) when the large Mexico City earthquake in September 1985 caused the marl reef surrounding Rincón lake to crack.

The varve sequence from Alberca covers the period AD 1852-1973 and the Rincón sequence the period AD 1839-1943. The varve thickness equals the annual sedimentation. In Alberca, the sedimentation rate ranges between 0.55 and $9.3 \mathrm{~mm} \mathrm{yr}^{-1}$. The sedimentation rate prior to 1911 generally exceeded the overall mean rate $\left(2.33 \mathrm{~mm} \mathrm{yr}^{-1}\right)$, but fell to levels below the mean thereafter. Within this sequence, nine turbidites were found, ranging between 1.5 and $37.85 \mathrm{~mm}$ in thickness. 
Table 3 Thickness of varve sublaminae and varve thickness (mm) from Alberca and Rincón

\begin{tabular}{|c|c|c|c|c|c|c|c|c|}
\hline \multirow[b]{2}{*}{$(\mathrm{mm})$} & \multicolumn{4}{|l|}{ Alberca } & \multicolumn{4}{|l|}{ Rincón } \\
\hline & Carbonate & Algae & Detritus & Varve & Carbonate & Algae & Detritus & Varve \\
\hline Minimum & 0.05 & 0.07 & 0.03 & 0.05 & 0.15 & 0.05 & 0.05 & 0.55 \\
\hline Mean & 0.43 & 0.88 & 1.17 & 2.23 & 0.53 & 0.4 & 0.58 & 1.43 \\
\hline Median & 0.30 & 0.60 & 0.90 & 1.78 & 0.50 & 0.35 & 0.45 & 1.35 \\
\hline Maximum & 2.45 & 4.05 & 4.65 & 9.30 & 1.70 & 2.10 & 2.35 & 4.40 \\
\hline
\end{tabular}

Fig. 9 Varve and tephrochonologies for (a) the Alberca sequence and (b) the Rincón sequence extended by ${ }^{210} \mathrm{~Pb}$. Ages calculated according to the CRS (constant rate of supply) model (Appleby and Oldfield 1978)

\section{A Hoya La Alberca}

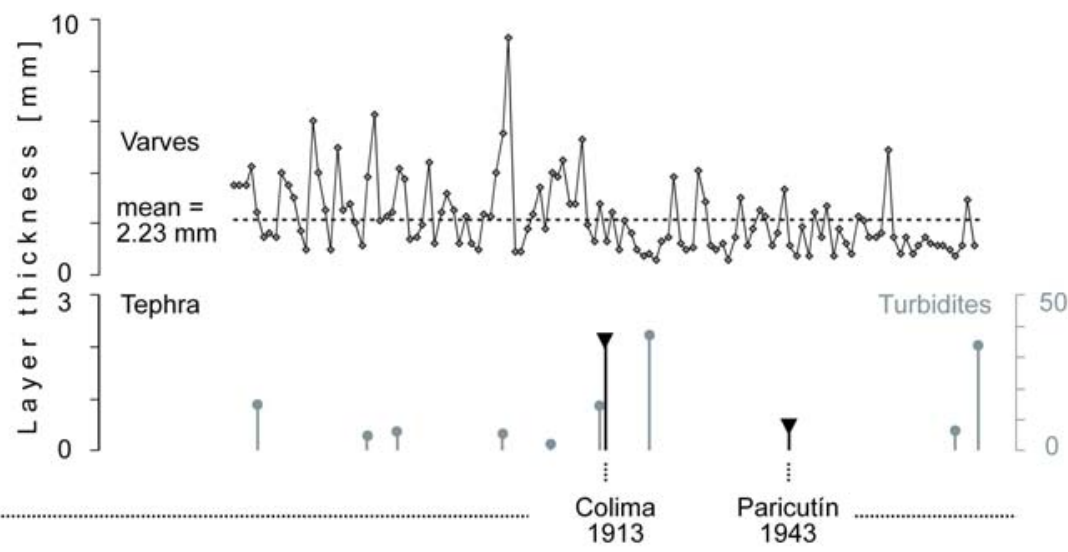

\section{B Hoya Rincón de Parangueo}

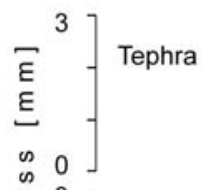

(1) 3

$\left.\begin{array}{ll}\stackrel{0}{c} & 3 \\ \text { ㄷ } & \\ \hline 0 & \end{array}\right]$
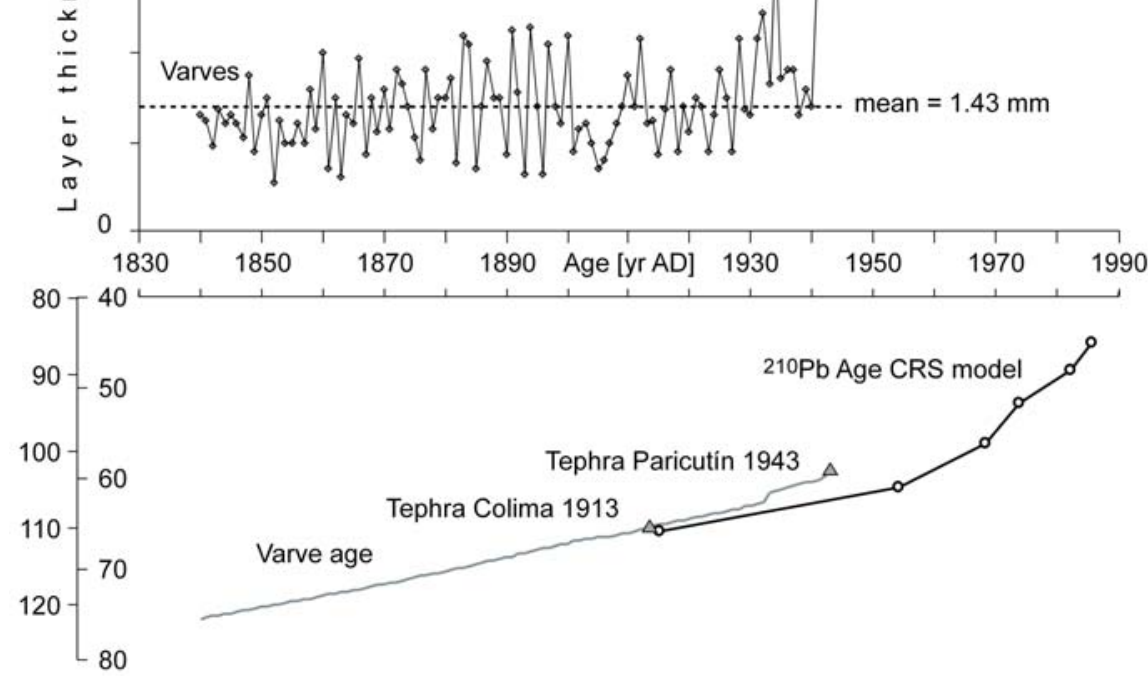

UCB MX

2004 RP3-1

Core depth [cm] 


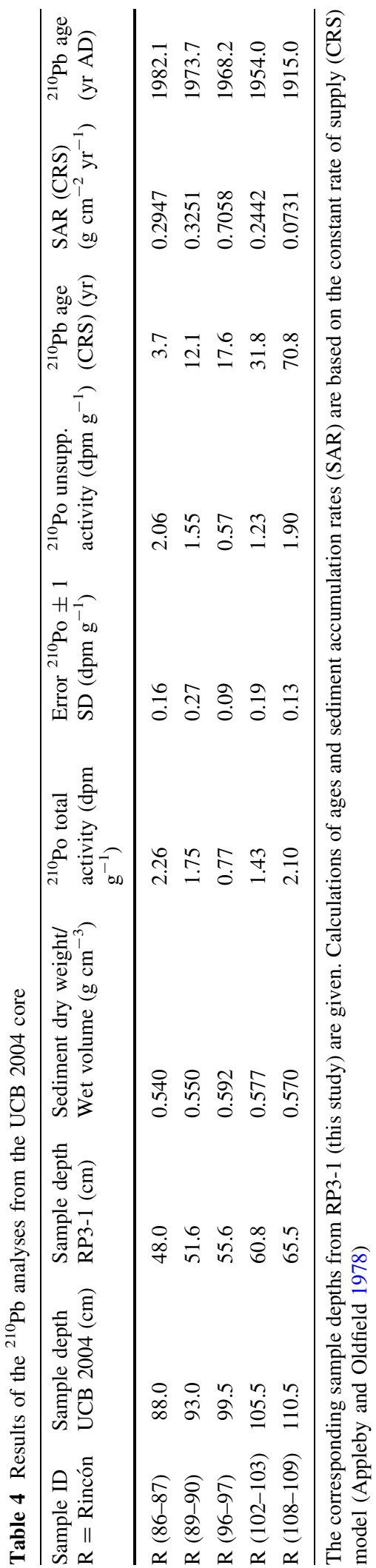

In Rincón, the sedimentation rate ranges between 0.55 and $4.4 \mathrm{~mm} \mathrm{yr}^{-1}$ with a mean value of $1.43 \mathrm{~mm}$ $\mathrm{yr}^{-1}$. Rates are below this average for the periods 1839-1880 and 1897-1925, while they are higher from 1881 to 1896 and after 1926. Only two turbidites were found: one is $6.8 \mathrm{~mm}$ thick and dates to 1932 , the other is $2.4 \mathrm{~mm}$ thick and dates to 1942 .

Element chemistry, varve sublaminae and principal components

Variations in element chemistry of the sediments were analysed by $\mu \mathrm{XRF}$ scanning. We determined the count rates of 10 elements: $\mathrm{Al}, \mathrm{Si}, \mathrm{S}, \mathrm{Cl}, \mathrm{K}, \mathrm{Ca}$, Ti, Mn, Fe, Sr (Fig. 10, Table 5). Chlorine was below detection limit in the Alberca sequence and was therefore not included in the ordinations. Ordinations were calculated for elements and annual sublaminae thicknesses. As the joint ordinations require equal scaling, we calculated annual mean count rates for the elements. Their relation to the point count data is shown for $\mathrm{Sr}$ in Fig. 10. The data series (all skewed positively) were transformed accordingly to obtain the normal distributions required for the ordinations.

Detrended correspondence analyses indicated short gradient lengths (0.46 SD for Alberca and 0.28 SD for Rincón), so we used PCA to identify patterns in the data. The PCA produced similar results for both cores (Fig. 11). The lithogenic elements ( $\mathrm{K}, \mathrm{Al}, \mathrm{Ti}$, and $\mathrm{Si}$ ) and the redox-sensitive elements ( $\mathrm{Fe}$ and $\mathrm{Mn}$ ) are positively correlated with the respective first principal components (PC1). Their co-occurrence with $\mathrm{S}$ suggests the presence of metal sulfides. The carbonate elements $(\mathrm{Ca}, \mathrm{Sr})$ are in close relation to the thickness of the carbonate layers. Also the thicknesses of algal and detrital layers are related in both localities. In Alberca, the development of the latter is connected more closely with that of the lithogenic elements than in Rincón, where lithogenic elements seem to occur in all sublaminae.

Allochthonous deposition-role of precipitation and wind

In order to check our assumption that detrital input is related to precipitation, we compared the sum of the annual precipitation from the closest weather station 
Fig. 10 Annual mean count rates of selected elements from the Alberca and Rincón sequences. For comparison, point counts are plotted for $\mathrm{Sr}$ (grey curves)

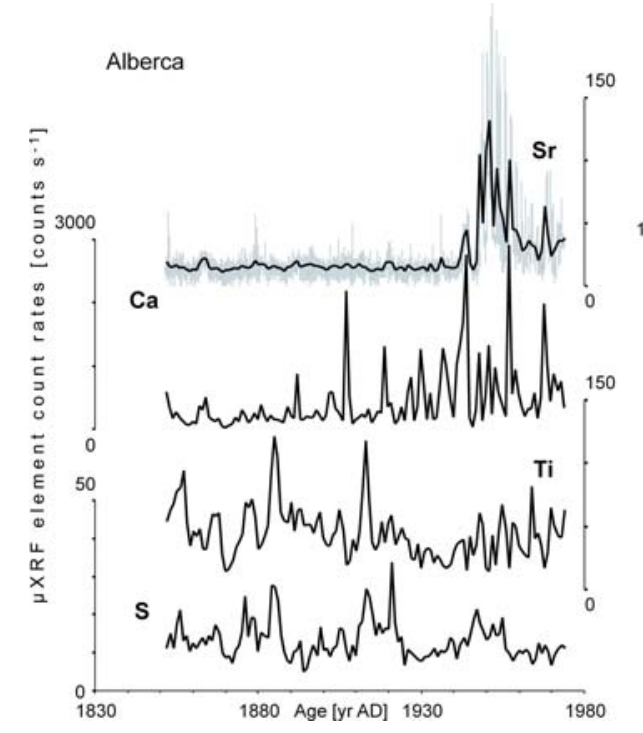

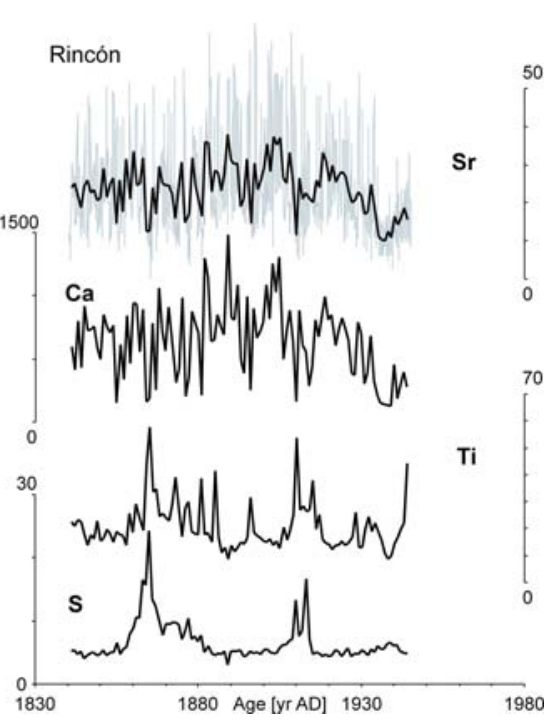

Table 5 Element counts from micro X-ray fluorescence spectrometry ( $\mu \mathrm{XRF}$ )

\begin{tabular}{|c|c|c|c|c|c|c|c|c|c|c|}
\hline Alberca (counts s ${ }^{-1}$ ) & $\mathrm{Al}$ & $\mathrm{Si}$ & $\mathrm{S}$ & $\mathrm{Cl}^{*}$ & $\mathrm{~K}$ & $\mathrm{Ca}$ & $\mathrm{Ti}$ & Mn & $\mathrm{Fe}$ & $\mathrm{Sr}$ \\
\hline Minimum & 0.0 & 6.3 & 0.0 & - & 0.0 & 0.7 & 0.9 & 0.0 & 11.4 & 0.0 \\
\hline Mean & 8.5 & 87.1 & 14.1 & - & 45.6 & 342.8 & 51.4 & 20.3 & 853.8 & 20.0 \\
\hline Median & 6.6 & 82.4 & 12.1 & - & 42.4 & 150.8 & 44.6 & 20.1 & 799.1 & 16.3 \\
\hline Maximum & 59.1 & 328.3 & 136.9 & - & 220.1 & 4162.1 & 349.3 & 106.7 & 3070.4 & 298.9 \\
\hline Rincón (counts s ${ }^{-1}$ ) & Al & $\mathrm{Si}$ & $\mathrm{S}$ & $\mathrm{Cl}$ & $\mathrm{K}$ & $\mathrm{Ca}$ & $\mathrm{Ti}$ & $\mathrm{Mn}$ & $\mathrm{Fe}$ & $\mathrm{Sr}$ \\
\hline Minimum & 0.0 & 4.7 & 0.7 & 49.9 & 3.2 & 7.2 & 1.4 & 0.0 & 47.3 & 0.0 \\
\hline Mean & 5.4 & 73.2 & 6.3 & 91.0 & 57.9 & 564.6 & 22.2 & 9.2 & 371.0 & 22.0 \\
\hline Median & 4.6 & 71.3 & 5.5 & 87.4 & 56.3 & 380.8 & 18.8 & 9.0 & 305.4 & 19.5 \\
\hline Maximum & 25.3 & 155.7 & 61.3 & 182.6 & 123.7 & 2965.3 & 137.6 & 25.1 & 1885.1 & 67.8 \\
\hline
\end{tabular}

* $\mathrm{Cl}$ was below detection limit in Alberca

in Valle de Santiago (1945-2001 with gaps in the early 1980s) with the variables for detrital input of Alberca (the varved Rincón sequence ends in 1943). The relation of annual precipitation and the annual mean counts of $\mathrm{Ti}$ (chosen as the most immobile of the lithogenic elements) is weak ( $r=0.36 ; N=27)$ (Fig. 12). The correlation between rainfall and detrital laminae thickness is even weaker. This may in part be due to the shortness and incompleteness of the precipitation data series, but could also suggest agents other than precipitation and runoff contributed allochthonous material to the lake. Detrital laminae thicknesses and Ti show similar development only for 5-year running means in Rincón. Consequently, Ti occurrence may not be exclusive to the detrital laminae identified under the microscope.

Dust storms are and have been observed frequently in Central Mexico (e.g. Jauregui 1989), mainly during the dry spring months. Then, loose material is available at the land surface, and dust particles are not washed out of the atmosphere by precipitation (Gillette et al. 1997; Jáuregui and Luyando 1999). Surfaces such as non-irrigated fields in the foothills and upland areas of the Valle de Santiago region, wasteland from overgrazing, or the floodplain of the Rio Lerma to the north and west provide highly winderodible sites (Alcocer et al. 2000; Gill 1996; Gillette et al. 1997). Remote transport may include material 

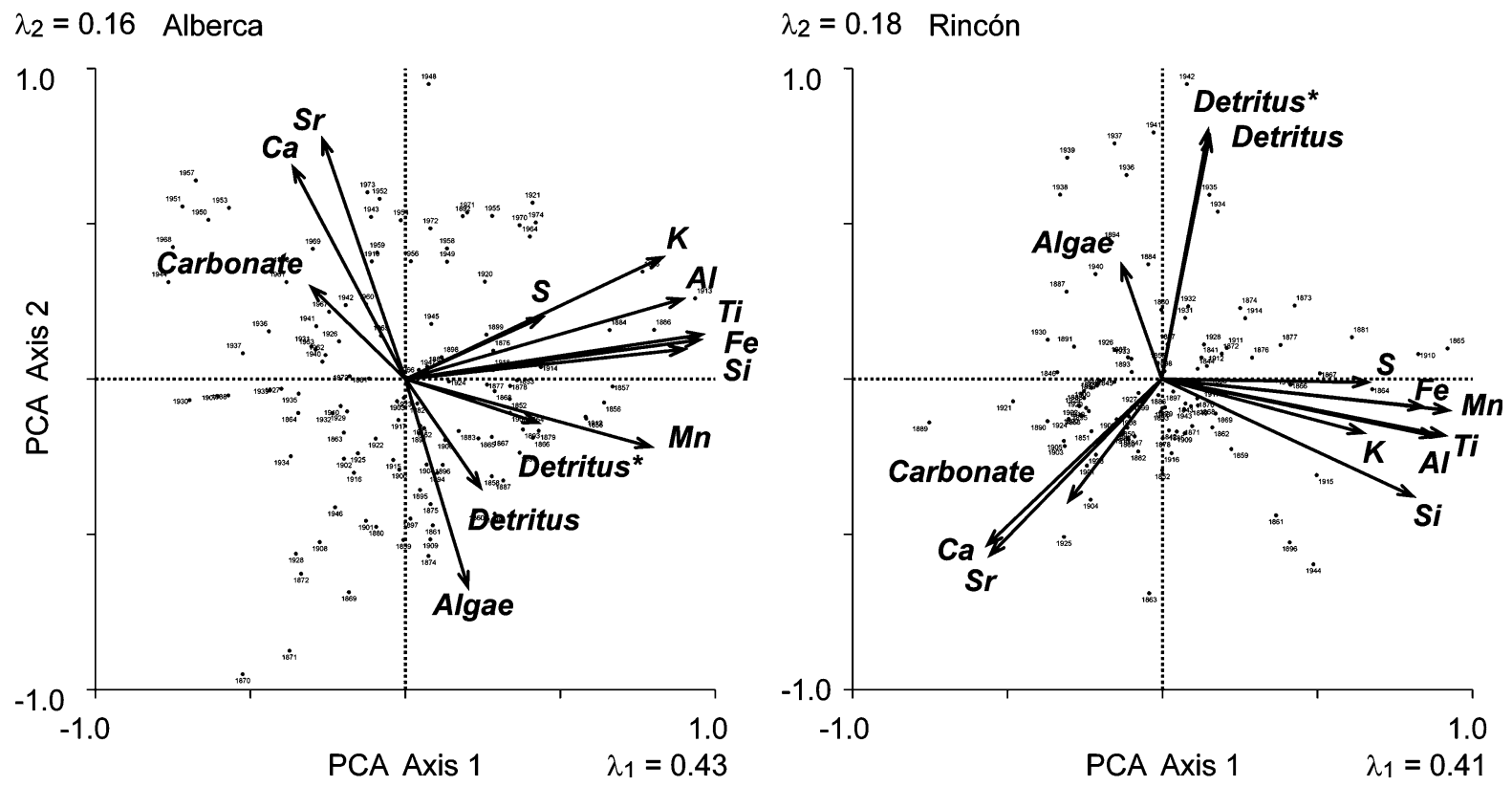

Fig. 11 Correlation of annual data of element chemistry and varve sublaminae thickness from the Alberca and Rincón sequences: biplots of the first two principal components. Detritus* includes the detrital laminae, the turbidites and the tephras

Fig. 12 Detritus deposition in Alberca and Rincón sequences in comparison with the annual precipitation sum from the station Valle de Santiago. Detritus is depicted as annual data and 5-yr running means (thick lines) of the Ti counts and the sum-thickness of detrital laminae (including turbidites and tephra layers)

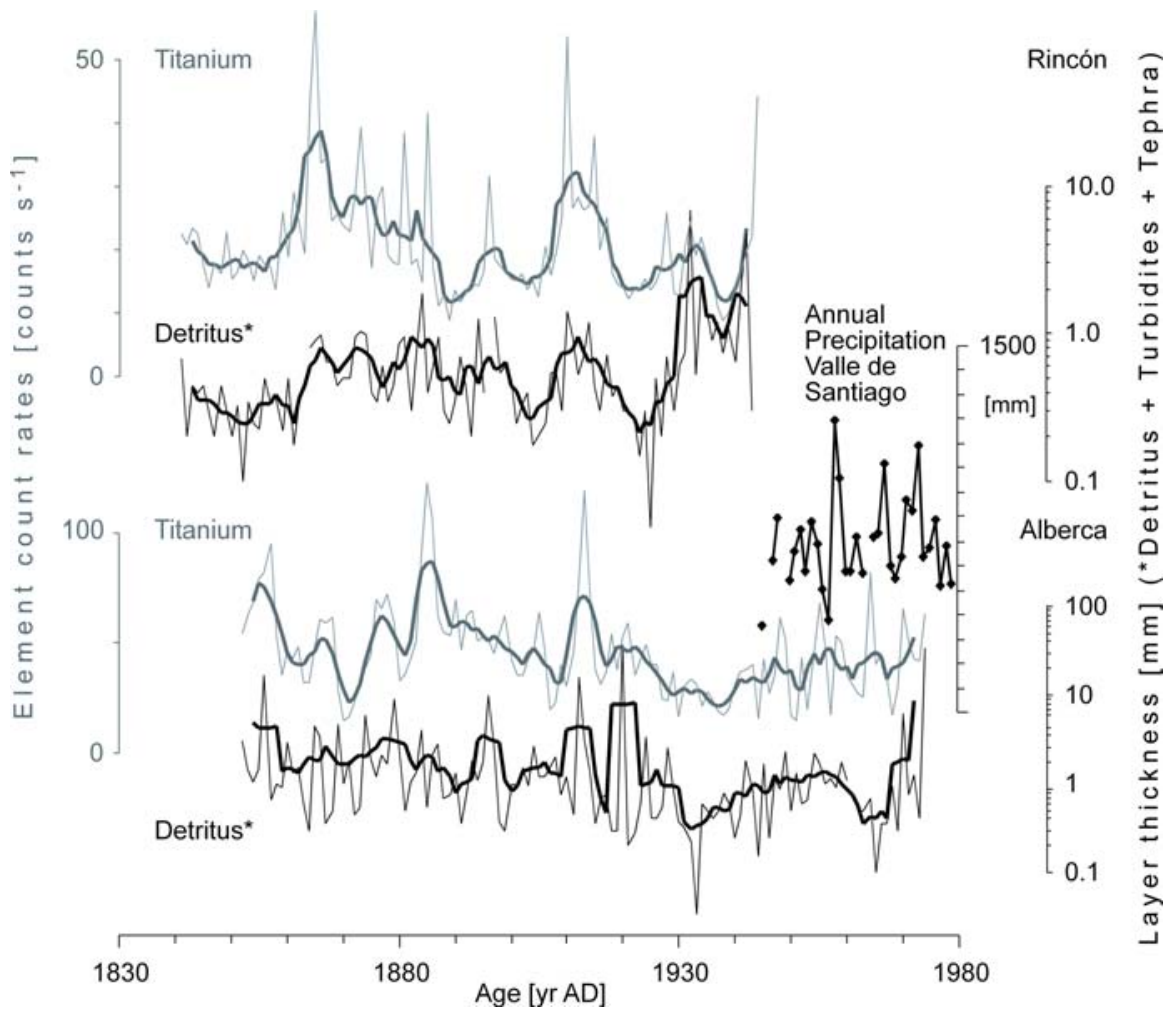

from the desert land to the north (Rivera Rivera 2006). The fine material is transported with the nortes, dry and cold meridional winter winds. Once temperature increases towards the end of the dry season, convective plumes and dust devils mobilize particles (Kaimal and Businger 1970; Rennó et al. 
1998). The eolian particles are then preferentially trapped in water bodies (Gill 1996), and in that way, lithogenic elements are deposited during the dry season.

Autochthonous deposition-role of nutrients, evaporation and human impact

Because algal remains are not exclusively concentrated in algal laminae, but also disseminated in the detrital laminae, the signal of autochthonous production is blurred. Algal laminae thickness is positively correlated with that of detritus laminae in Rincón ( $r=0.54, p<10^{-6}$ ) and may hint at a coupling of algal blooms to nutrients that enter the lake with the detrital material. Additionally, turbulence may cause recycling of nutrients stored in the hypolimnion.

Calcium and $\mathrm{Sr}$, with peak counts in the authigenic carbonates, are correlated in both sequences (Rincón $r=0.92, \quad N=104 ;$ Alberca $r=0.53, N=123$ ) (Figs. 10, 11). The stronger correlation in Rincón hints at a constant composition (aragonite and hydromagnesite), as in the sub-sampled carbonate laminae (Fig. 7). The increases of Ca after 1900 and of $\mathrm{Sr}$ after 1940 in Alberca relate to a change in mineralogy. Synchronous with the $\mathrm{Sr}$ increase, monohydrocalcite changes to aragonite (Figs. 7, 13). This is in agreement with a higher capacity of aragonite to accommodate $\mathrm{Sr}$ in the lattice compared to calcite (Wray and Daniels 1957).

The occurrence of aragonite is frequently related to closed-basin conditions (Glenn and Kelts 1991). Such conditions prevailed in Alberca, in the strict sense, after the springs within the maar dried up in the 1940s (Alcocer et al. 2000). At the same time, the number of deep wells in Guanajuato increased in relation to the development of irrigation agriculture, which supported a growing number of inhabitants (Sandoval 2004; Fig. 13). Groundwater levels dropped by $2-3 \mathrm{~m} \mathrm{a}^{-1}$, and after 1970 lake levels responded as depicted in Fig. 2. The exponential increase of $\mathrm{Cl}$ counts in Rincón, starting in the early 1930s, likely relates to soil salinization, a known consequence of irrigated agriculture in arid regions (Banin and Fish 1995; Salama et al. 1999). The signal is secondary, as substantiated by its early timing compared to the onset of irrigation. Park et al. (under review) relate this signal to the infiltration of water with increased salt content.

Autochthonous versus allochthonous deposition-droughts and ENSO

The relation of allochthonous versus autochthonous input was analysed in highest resolution by moving correlation (5-year windows) of the point counts of $\mathrm{Ti}$
Fig. 13 Anthropogenic influence on the deposition of carbonates and salt: annual-mean element counts of $\mathrm{Cl}$ (Rincón), $\mathrm{Sr}$ and $\mathrm{Ca}$ (Alberca) and the development of the number of deep wells and inhabitants in Guanajuato (modified after Sandoval 2004)

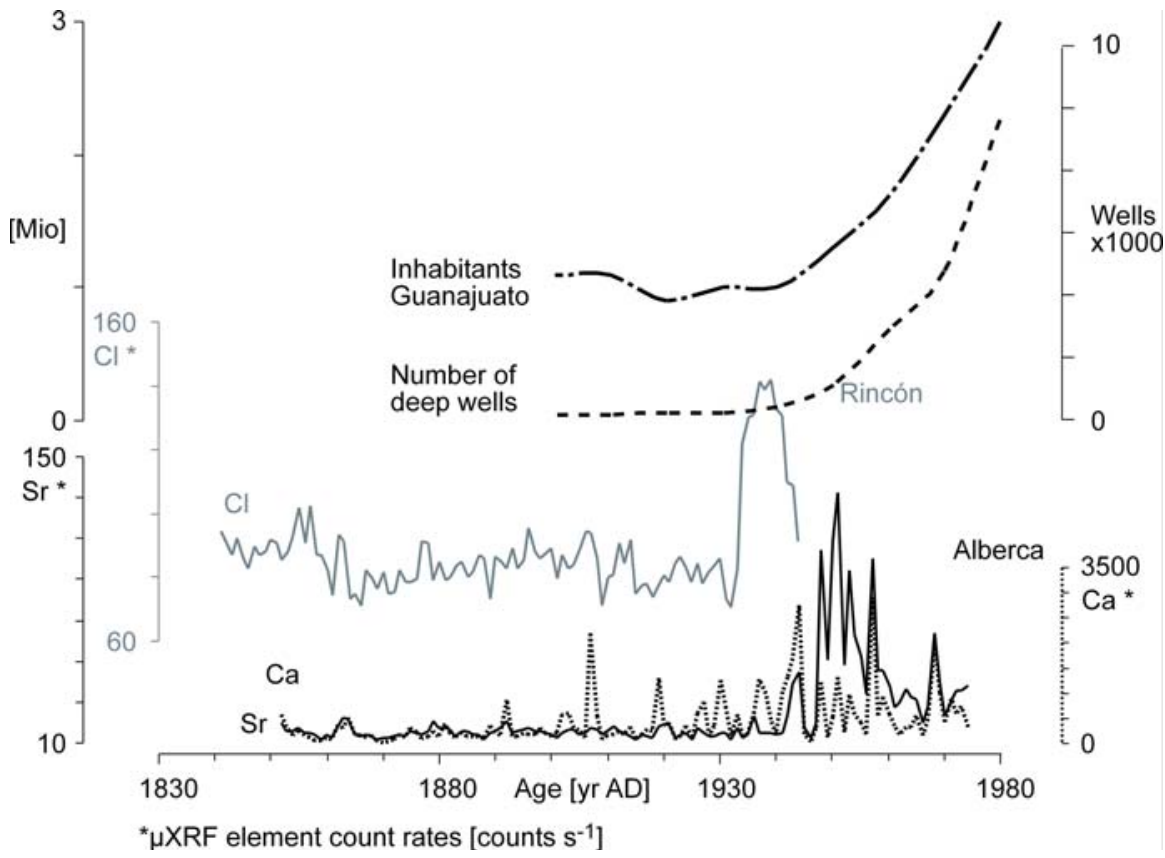




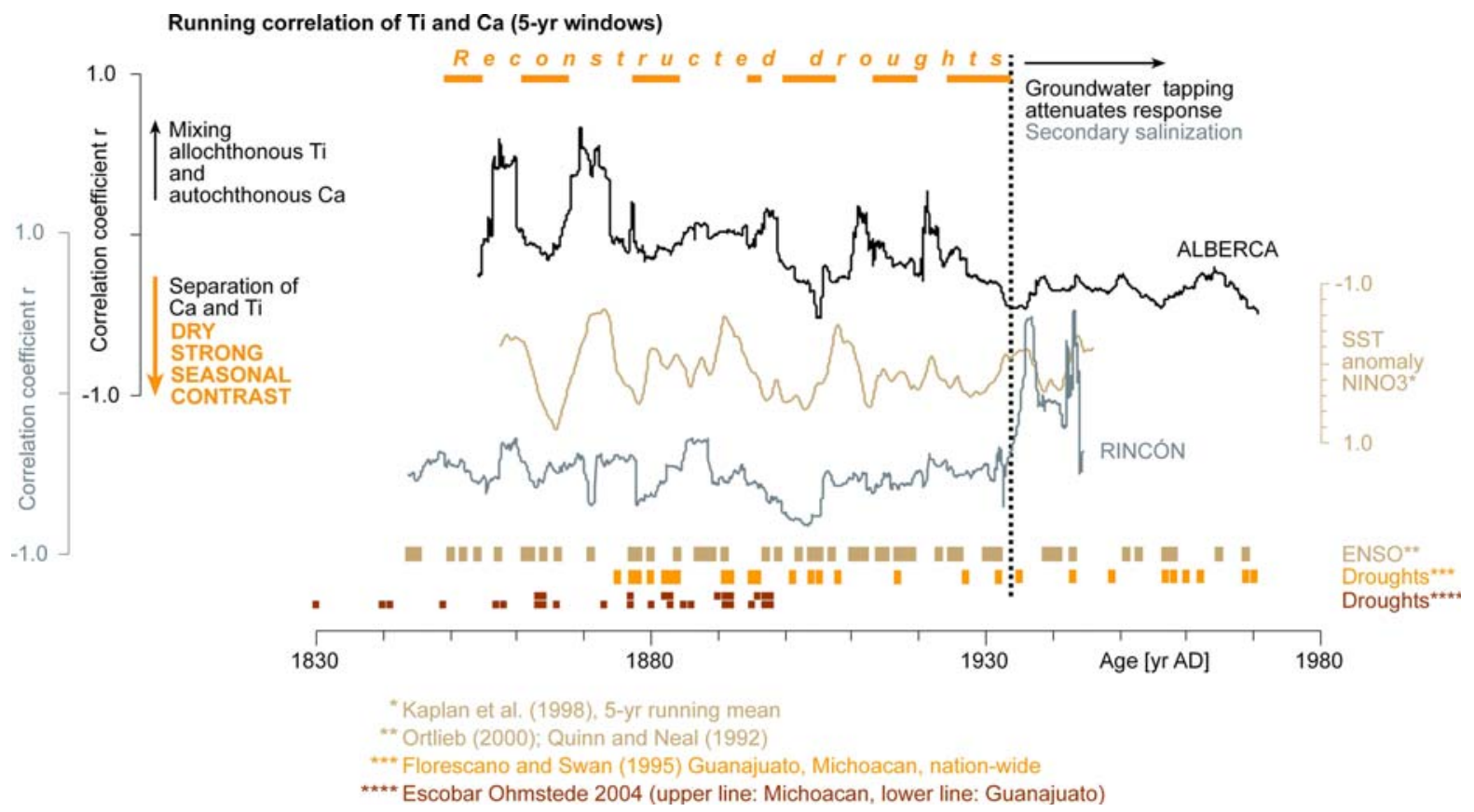

Fig. 14 Moving correlations of the $\mathrm{Ca}$ and $\mathrm{Ti}$ point counts (5-yr windows) in comparison with reconstructed anomalies of sea surface temperature (SST) (Kaplan et al. 1998), historic El

(highest in the allochthonous, detrital laminae), and $\mathrm{Ca}$ (highest in the autochthonous, carbonate laminae) (Fig. 14). The 5-year windows include 86 points in Rincón and 386 points in Alberca according to the mean annual layer thicknesses and the measuringstep sizes (Table 3 ). We concluded that negative correlations of $\mathrm{Ca}$ and $\mathrm{Ti}$ reflect a separation of these elements in the respective sublayers due to a strong seasonal contrast with rainfall confined to the summer months, pronounced evaporation in winter, and calm sedimentation conditions. Positive correlations of $\mathrm{Ca}$ and $\mathrm{Ti}$, in turn, indicate mixing beyond the respective sublaminae-boundaries.

The calculated correlation coefficients (r) show similar developments for both sequences until the 1930s, when the sudden increase of $\mathrm{Cl}$ occurs in Rincón. We suspect that re-crystallization of halite influenced the detection of the other elements in such a way that all other counts were underestimated (Fig. 11). Therefore, we excluded this part of the Rincón sequence from the following considerations.

Negative swings of the Ca-Ti correlations coincide with years of historic droughts (Florescano and Swan, 1995; Escobar Ohmstede 2004). We extracted
Niño (Quinn and Neal 1992; Ortlieb 2000), and regional droughts compiled by Florescano and Swan (1995) and Escobar Ohmstede (2004)

reports of drought for Guanajuato and Michoacàn from Escobar Ohmstede (2004) and from Florescano and Swan (1995), and nation-wide events from Florescano and Swan (1995).

Reports of drought do not exist for each negative swing, which may reflect the incompleteness of the documentary record. Only in $44 \%$ of the cases do the reports of drought coincide with reports of historic El Niño (Ortlieb 2000; Quinn and Neal 1992). If we extend the time range of droughts to the 1 year following an El Niño (because we suspect El Niño causes the droughts), the percentage of coincidence increases to $73.3 \%$. For the period 1450-1900, Mendoza et al. (2005) found significant links between droughts and moderate to very strong El Niños in the Quinn and Neal compilation (1992), and a high correlation with very strong El Niños compiled in Ortlieb (2000). Furthermore, not all historic El Niños are consistent with reconstructed SSTs (Kaplan et al. 1998). The combination of the respective series: documentary droughts and El Niño, and reconstructed SSTs (5-yr running means), with negative excursions of the $\mathrm{Ca}-\mathrm{Ti}$ correlation (5-yr windows), results in a consistent pattern of drier conditions (Fig. 14). Substantiation for decreased summer 
precipitation in Central Mexico during El Niño conditions comes from studies by Magaña et al. (2003) and Mendoza et al. (2005).

According to the Alberca and Rincón records, dry conditions occurred frequently-severe droughts covered 5- to 7-year periods centred around the early 1850s, 1865, 1880, and 1905. A short drought was centred around 1895, and a series of dry years in the 1920s continued into the mid 1930s. Drier conditions in the early 1850 s and during the 1860 s are in accordance with tree-ring reconstructions (Cleaveland et al. 2003). After 1940, the amplitude of the response in our data series seems attenuated and is most likely overprinted by the increasing groundwater exploitation in the Valle de Santiago region.

Site-specific differences

We observe different sedimentation responses in Alberca and Rincón with respect to a number of variables, although the climate conditions must have been similar because of their proximity. In Alberca, allochthonous deposition is higher and positive excursions of the Ca-Ti correlation are more pronounced. Also, the sedimentation rates in Alberca exceed those in Rincón. We suggest this is a consequence of the less steep crater walls of the Rincón maar combined with the marl reef that must have effectively trapped coarse-grained sediment washed in during the rainy season. On the other hand, the higher frequency of turbidites in Alberca indicates greater susceptibility of the steeper-sloped crater to erosion.

The average thickness of the carbonate laminae in Rincón $\left(0.53 \mathrm{~mm} \mathrm{yr}^{-1}\right)$ is greater than in Alberca $\left(0.43 \mathrm{~mm} \mathrm{yr}^{-1}\right)$ (Table 3$)$. The tenfold higher electrical conductivity of Rincón (Table 1; Green 1986), together with the heavier carbon and oxygen isotope ratios, may reflect a higher rate of evaporation from Rincón, supported by factors like wind movement and solar radiation receipt, related to the larger lake surface and crater area of Rincón, compared to Alberca (Table 1). The presence of a marl reef at Rincón in turn, would support the conclusion that algal photosynthesis was higher there than at Alberca.

\section{Conclusions}

We studied the densely laminated lacustrine sequences of two maar lakes, Hoya La Alberca and
Hoya Rincón de Parangueo, located in the Valle de Santiago in the central Trans-Mexican Volcanic Belt. Lamination in both sequences includes light carbonatic layers (aragonite, monohydrocalcite and hydromagnesite, enriched in ${ }^{13} \mathrm{C}$ and ${ }^{18} \mathrm{O}$ ) and dark laminae of clastic material (plagioclase and quartz) and fine organic detritus. Algal remains occur either concentrated in sublaminae or scattered in dark laminae. Principal components of varve sublaminae thickness and annual mean counts of elements analyzed by micro X-ray fluorescence spectrometry are (i) lithogenic elements (e.g. K, Al, Ti, and $\mathrm{Si}$ ) cooccurring with $\mathrm{S}$, (ii) $\mathrm{Ca}$ and $\mathrm{Sr}$ counts peaking in carbonate sublaminae, (iii) and algal layers associated with detritus layers and the lithogenic elements. This argues for the coupling of the laminae formation to the strong seasonal contrast. During the dry season, increased evaporation caused the precipitation of carbonates, while abundant summer rainfall caused surface runoff that transported detritus into the lake. Using these results we established varve chronologies in conjunction with ${ }^{210} \mathrm{~Pb}$ dates and two tephra dates attributed to eruptions of the volcanoes Fuego de Colima 1913 and Paricutín 1943. The varves cover the periods AD 1852-1973 for Alberca and AD 1839-1943 for Rincón.

Detritus deposition and local precipitation for Alberca are related, but not significantly correlated. This may originate from the shortness and incompleteness of the instrumental data. However, eolian input may also contribute to dry season deposition and would then confound the signal.

Moving correlations of $\mathrm{Ca}$ and $\mathrm{Ti}$ (5-yr windows) reveal a similar development of autochthonous versus allochthonous deposition in both sequences. Negative correlations, i.e. the separation of $\mathrm{Ti}$ and $\mathrm{Ca}$ in sublaminae, allow the reconstruction of droughts based on their correspondence with combined historic and reconstructed droughts, and El Niño events. Accordingly, droughts were frequent, but severe for the following 3-to-7-year periods centred around the early 1850s, 1865, 1880, 1895, 1905, 1915, and the late 1920s, with continuation into the 1930s. Subsequently, the already critical state of both lake systems was further aggravated by groundwater overexploitation due to the expansion of irrigated agriculture in the region after 1940. The drop of groundwater levels was followed by decrease in lake levels, desiccation of springs, and salinization of the natural waters. This 
process is evident in the transition from calcite to aragonite precipitation in Alberca (after 1940), predated by the occurrence of secondary halite from infiltration in Rincón after 1930.

The sensitivity of both lakes to changes in moisture availability differs. Drought response was more pronounced at Rincón, the maar with the larger size and therefore higher solar radiation receipt, evaporation, conductivity and heavier isotope signature of the carbonates. External input response is enhanced in Alberca, the smaller, steeper-sloped maar.

Acknowledgments The study was funded by the Deutsche Forschungsgemeinschaft within the IODP/ODP priority program (HA 2756/8). We thank M. Köhler for the excellent preparation of thin sections, B. Plessen for stable isotope analyses, R. Naumann for conducting the RDA analyses, H. Vos for help with statistical analyses, and Gildardo Gonzalez for assistance in the field. We thank two anonymous reviewers for their helpful comments.

Open Access This article is distributed under the terms of the Creative Commons Attribution Noncommercial License which permits any noncommercial use, distribution, and reproduction in any medium, provided the original author(s) and source are credited.

\section{References}

Aguilera Gómez LI (1991) Estudio Floristico y Sinecologico de la Vegetación en el crater "Hoya Rincón de Parangueo", Valle de Santiago, Gto. Colegio de Postgraduados, Montecillo

Alcocer J, Escobar E (1996) Limnological regionalization of Mexico. Lake Reserv Manag 2:55-69

Alcocer J, Escobar E, Lugo A (2000) Water use (and abuse) and its effects on the crater-lakes of Valle de Santiago, Mexico. Lake Reserv Manag 5:145-149

Appleby PG, Oldfield F (1978) The calculation of lead-210 dates assuming a constant rate of supply of unsupported ${ }^{210} \mathrm{~Pb}$ to the sediment. Catena $5: 1-8$

Banin A, Fish A (1995) Secondary desertification due to salinization of intensively irrigated lands: The Israeli experience. Environ Monit Assess 37:17-37

Bergmann J, Friedel P, Kleeberg R (1998) BGMN-A new fundamental parameters based Rietveld program for laboratory X-ray sources, its use in quantitative analysis and structure investigations. CPD Newsl 20:5-8

Bernal-Brooks FW, Dávalos-Lind L, Lind OT (2003) Seasonal and spatial variation in algal growth potential and growthlimiting nutrients in a shallow endorheic lake: Lake Pátzcuaro (Mexico). Lake Reserv Manag 8:83-93

Brauer A, Endres C, Günter C, Litt T, Stebich M, Negendank JFW (1999) High resolution sediment and vegetation responses to Younger Dryas climate change in varved lake sediments from Meerfelder Maar, Germany. Quat Sci Rev 18:321-329

Brauer A, Wulf S, Mangili C, Appelt O, Moscariello A (2007) Reply: tephrochronological dating of varved interglacial lake deposits from Piànico-Sèllere (Southern Alps, Italy) to around $400 \mathrm{ka}$ : a reply to D. Pinti, V. Rouchon, X. Quidelleur, P.-Y. Gillot, S. Chiesa, C. Ravazzi. J Quat Sci 22:415-418

Brooks SJ, Birks HJB (2000) Chironomid-inferred late-glacial and early-Holocene mean July air temperatures for Kråkenes Lake, western Norway. J Paleolimnol 23:77-89

Brown RB (1984) The paleoecology of the northern frontier of Mesoamerica. Doctoral thesis. University of Arizona, Tucson

Caballero M, Vázquez G, Lozano-García S, Rodríguez A, Sosa-Nájera S, Ruiz-Fernández AC, Ortega B (2006) Present limnological conditions and recent (ca. $340 \mathrm{yr}$ ) palaeolimnology of a tropical lake in the Sierra de Los Tuxtlas, Eastern Mexico. J Paleolimnol 35:83-97

Cleaveland MK, Stahle DW, Therrell MD, Villanueva-Diaz J, Burns BT (2003) Tree-ring reconstructed winter pecipitation and tropical teleconnections in Durango, Mexico. Clim Change 59:369-388

Coshell L, Rosen MR, McNamara KJ (1998) Hydromagnesite replacement of biomineralized aragonite in a new location of Holocene stromatolites, Lake Walyungup, Western Australia. Sedimentology 45:1005-1018

Davies SJ, Metcalfe SE, MacKenzie AB, Newton AJ, Endfield GH, Farmer JG (2004) Environmental changes in the Zirahuén Basin, Michoacán, Mexico, during the last 1000 years. J Paleolimnol 31:77-98

De la Cruz-Reyna S (1993) Random patterns of occurrence of explosive eruptions at Colima Volcano, Mexico. J Volcanol Geotherm Res 55:51-68

Eakins JD, Morrison RT (1978) A new procedure for the determination of Lead-210 in lake and marine sediments. Int J Appl Radiat Isot 29:531-536

Endfield GH, Fernandez Tejedo I (2006) Decades of drought, years of hunger: archival investigations of multiple year droughts in late Colonial Chihuahua. Clim Change 75: 391-419

Endfield GH, O’Hara SL (1999) Degradation, drought and dissent: an environmental history of colonial Michoacán, West Central Mexico. Ann Assoc Am Geogr 89:402-419

Escobar Ohmstede A (2004) Desastres Agrícolas en México: catálogo histórico vol 2 Siglo XIX (1822-1900). Fondo de Cultura Económica and CIESAS

Fahraeus LE, Slatt RM, Nowlan GS (1974) Origin of carbonate pseudopellets. J Sediment Res 44:27-29

Florescano E, Swan S (1995) Breve historia de la sequía en México. Bibliotheca Universidad Veracruzana, Veracruz

Freytet P, Verrecchia EP (2002) Lacustrine and palustrine carbonate petrography: an overview. J Paleolimnol 27: 221-237

Fries CJ Jr (1953) Volumes and weights of pyroclastic material, lava and water erupted by Paricutín volcano, Michoacán, México. Trans Am Geophys Union 34: 603-616

Gadow H (1930) Jorullo: the history of the volcano of Jorullo and the reclamation of the devastated district by animals and plants. Cambridge University Press, London 
Gill TE (1996) Eolian sediments generated by anthropogenic disturbance of playas: human impacts on the geomorphic system and geomorphic impacts on the human system. Geomorphology 17:207-228

Gillette DA, Fryrear DW, Gill TE, Ley T, Cahill TA, Gearhart EA (1997) Relation of vertical flux of particles smaller than $10 \mu \mathrm{m}$ to total aeolian horizontal mass flux at Owens Lake. J Geophys Res 102:26009-26015

Glenn CR, Kelts K (1991) Sedimentary rhythms in lake deposits. In: Einsele G, Ricken W, Seilacher A (eds) Cycles and events in stratigraphy. Springer, Berlin, pp 188-221

González BM, Ramírez JJ, Navarro C (2002) Summary of the historical eruptive activity of Volcán De Colima, Mexico 1519-2000. J Volcanol Geotherm Res 117:21-46

Green J (1986) Associations of zooplankton in six crater lakes in Arizona, Mexico and New Mexico. J Zool 208:135-139

Hasenaka T, Carmichael ISE (1985) The Michoacán-Guanajuato volcanic field, central Mexico. Estimation of eruption age and volume of cinder cones. J Volcanol Geotherm Res 25:105-124

Hasenaka T, Carmichael ISE (1987) The cinder cones of Michoacán-Guanajuato, central Mexico: petrology and chemistry. J Petrol 28:241-269

Hernandez-Aviles J, Bernal-Brooks F (2001) The algal growth potential and algae groth-limiting nutrients from 30 of Mexico's lakes and reservoirs. Verhandlungen Internationale Vereinigung für Limnologie 27:3583-3588

Hill MO, Gauch HG (1980) Detrended correspondence analysis: an improved ordination technique. Plant Ecol 42: $47-58$

Hunt JB, Hill PG (1996) An inter-laboratory comparison of the electron probe microanalysis of glass geochemistry. Quat Int 34-36:229-241

Jauregui E (1989) The dust storms of Mexico city. Int J Climatol 9:169-180

Jauregui E (1997) Climate changes in Mexico during the historical and instrumented periods. Quat Int 43-44:7-17

Jáuregui E, Luyando E (1999) Global radiation attenuation by air pollution and its effects on the thermal climate in Mexico city. Int J Climatol 19:683-694

Kaimal JV, Businger JA (1970) Case studies of a convective plume and a dust devil. J Appl Meteorol 9:612-620

Kaplan A, Cane MA, Kushnir Y, Clement AC, Blumenthal MB, Rajagopalan B (1998) Analyses of global sea surface temperature 1856-1991. J Geophys Res 103:18567-18590

Kienel U, Schwab M, Schettler G (2005) Distinguishing climatic from direct anthropogenic influences during the past 400 years in varved sediments from Lake Holzmaar (Eifel, Germany). J Paleolimnol 33:327-347

Le Bas MJ, Le Maitre RW, Streckeisen A, Zanettin B (1986) A chemical classification of volcanic rocks based on the total alkali-silica diagram. J Petrol 27:745-750

Legendre P, Legendre L (1998) Numerical ecology, 2nd edn. Elsevier, Amsterdam

Leng MJ, Lamb AL, Heaton THE, Marshall JD, Wolfe BB, Jones MD (2006) Isotopes in lake sediments. In: Leng MJ et al (eds) Isotopes in paleoenvironmental research. Springer, Dordrecht, pp 147-184

Leng MJ, Metcalfe SE, Davies SJ (2005) Investigating late Holocene climate variability in central Mexico using carbon isotope ratios in organic material and oxygen isotope ratios from diatom silica within lacustrine sediments. J Paleolim 34:413-431

Li H-C, Ku T-L (1997) $\delta^{13} \mathrm{C}-\delta^{18} \mathrm{O}$ covariance as a paleohydrological indicator for closed-basin lakes. Palaeogeogr Palaeoclimatol Paleoecol 133:69-80

Lind OT, Doyle R, Vodopich DS, Trotter BG, Gualberto Limón J, Dávalos-Lind L (1992) Clay turbidity: regulation of phytoplankton production in a large, nutrient-rich tropical lake. Limnol Oceanogr 37:549-565

Luhr JF (1992) Slab-derived fluids and partial melting in subduction zones: insights from two contrasting Mexican volcanoes (Colima and Ceboruco). J Volcanol Geotherm Res 54:1-18

Luhr JF (2000) The geology and petrology of Volcan San Juan (Nayarít, Mexico) and the compositionally zoned Tepic pumice. J Volcanol Geotherm Res 95:109-156

Luhr JF (2001) Glass inclusions and melt volatile contents at Paricutín Volcano, Mexico. Contrib Mineral Petrol 142: 261-283

Luhr JF, Carmichael ISE (1985) Jorullo volcano, Michoacán, Mexico (1759-1774): the earliest stages of fractionation in calc-alkaline magmas. Contrib Mineral Petrol 90: 142-161

Luhr JF, Kyser TK (1989) Primary igneous analcime; the Colima minettes. Am Mineral 74:216-223

Luhr JF, Carmichael ISE, Varekamp JC (1984) The 1982 eruptions of El Chichón volcano, Chiapas, Mexico: mineralogy and petrology of the anhydrite-bearing pumices. J Volcanol Geotherm Res 23:69-108

Magaña VO, Vázquez JL, Pérez JL, Pérez JB (2003) Impact of El Niño on precipitation in Mexico. Geofisica Internacional 42:313-330

McKenzie JA (1985) Carbon isotopes and productivity in the lacustrine and marine environment. In: Stumm W (ed) Chemical processes in lakes. Wiley, New York, pp 99-118

Mendoza B, Jáuregui E, Diaz-Sandoval R, García-Acosta V, Velasco V, Cordero G (2005) Historical droughts in central Mexico and their relation with El Nino. J Appl Meteorol 44:709-716

Metcalfe SE (1987) Historical data and climate change in Mexico a review. Geogr J 153:211-222

Metcalfe SE (1995) Holocene environmental change in the Zacapu Basin, México: a diatom-based record. Holocene 5:196-208

Metcalfe SE, Davies SJ (2007) Deciphering recent climate change in central Mexican lake records. Clim Change 83: 169-186

Metcalfe SE, Street-Perrott FA, Brown RB, Hales PA, Perrott RA (1989) Late Holocene human impact on lake basins in Central Mexico. Geoarchaeology 4:119-141

Metcalfe SE, O'Hara SL, Caballero ME, Davies SJ (2000) Records of Late Pleistocene-Holocene climatic change in Mexico-a review. Quat Sci Rev 19:699-721

Meyers PA, Lallier-Vergés E (1999) Lacustrine sedimentary organic matter records of late quaternary paleoclimates. J Paleolimnol 21:345-372

Moore JJ, Hughen KA, Miller GH, Overpeck JT (2001) Little Ice Age recorded in summer temperature reconstruction from varved sediments of Donard Lake, Baffin Island, Canada. J Paleolimnol 25:503-517 
Mora JC, Macías JL, Saucedo R, Orlando A, Manetti P, Vaselli O (2002) Petrology of the 1998-2000 products of Volcán de Colima, México. J Volcanol Geotherm Res 117:195-212

Moreno H (1986) Diario del viaje a la Nueva España de Francisco de Ajofrin SEP. Cien Mexico, Mexico City

Murphy GP (1986) The chronology, pyroclastic stratigraphy and petrology of the Valle de Santiago Maar Field. Central Mexico. University of California, Berkeley, p 55

Newton AJ, Metcalfe SE, Davies SJ, Cook G, Barker P, Telford RJ (2005) Late quaternary volcanic record from lakes of Michoacán, central Mexico. Quat Sci Rev 24:91-104

O'Hara SL (1993) Historical evidence of fluctuations in the lake level of Lake Pátzcuaro, Michoacán, Mexico over the last 600 years. Geogr J 159:51-62

Oliva MG, Lugo A, Alcocer J, Peralta L, del Rosatio Sanchez M (2001) Phytoplankton dynamics in a deep, tropical, hyposaline lake. Hydrobiologia 466:299-306

Ordoñez E (1906) Los cráteres de explosión de Valle de Santiago 10th Congress. Geol Intern, Excursion Field guide, pp 1-8

Orozco F, Madinaveitia A (1941) Estudio químico de los lagos alcalinos. Annales del Instistuto Biología de la Universidad Nacionál Autonoma de México 12:429-438

Ortega-Guerrero B, Newton AJ (1998) Geochemical characterization of Late Pleistocene and Holocene tephra layers from the Basin of Mexico, Central Mexico. Quat Res 50:90-106

Ortlieb L (2000) The documentary historical record of El Niño events in Peru: an update of the Quinn record (Sixteenth through nineteenth centuries). In: Diaz HF, Markgraf V (eds) El Niño and the southern oscillation, multiscale variability and global and regional impacts. Cambridge, Cambridge University Press, pp 207-295

Park J, Byrne R, Böhnel H, Molina Garza R, Kienel U (under review) A record of pre- and post-conquest environmental change from Hoya Rincón de Paragueo, a maar lake in the Valle de Santiago of Guanajuato, Mexico. Quat Res

Quinn WH, Neal VT (1992) The historical record of El Niño events. In: Bradley RS, Jones PD (eds) Climate since A.D. 1500. Routledge, London, pp 623-648

Rennó NO, Burkett ML, Larkin MP (1998) A simple thermodynamical theory for dust devils. J Atmos Sci 55:3244-3252

Rivera Rivera NI (2006) Detection and characterization of dust source areas in the Chihuahuan desert, Southwest North America Faculty of the Graduate School, Environmental Sciences Program. Master thesis, University of Texas at El Paso, El Paso, p 30

Robin C, Boudal C (1987) A gigantic Bezymianny-type event at the beginning of modern Volcan Popocatepetl. J Volcanol Geotherm Res 31:115-130

Rose WI (1987) Santa María, Guatemala: Bimodal soda-rich calc-alkalic stratovolcano. J Volcanol Geotherm Res 33: 109-129

Salama RB, Otto CJ, Fitzpatrick RW (1999) Contributions of groundwater conditions to soil and water salinization. Hydrogeol J 7:46-64

Sandoval R (2004) A participatory approach to integrated aquifer management: the case of Guanajuato State, Mexico. Hydrogeol J 12:6-16

Saucedo R, Macías JL, Sheridan MF, Bursik MI, Komorowski JC (2005) Modelling of pyroclastic flows of Colima Volcano, Mexico: implications for hazard assessment. J Volcanol Geotherm Res 139:103-115
Schettler G, Mingram J, Negendank JFW, Jiaqi L (2006) Palaeovariations in the East-Asian monsoon regime geochemically recorded in varved sediments of Lake Sihailongwan (Northeast China, Jilin Province). Part 2: a 200-year record of atmospheric lead-210 flux variations and its palaeoclimatic implications. J Paleolimnol 35:271-288

Self S, Rampino MR, Carr MJ (1989) A reappraisal of the 1835 eruption of Cosigüina and its atmospheric impact. B Volcanol 52:57-65

Servicio Meteorologico Nacional Comisión Nacional del Agua del Servicio Meteorológico Nacional, http://smn.cna.gob. $\mathrm{mx} /$ productos/normales/estacion/normales

Siebert L, Simkin T (2002) Volcanoes of the world: an illustrated catalog of Holocene volcanoes and their eruptions. Smithsonian Institution, Global Volcanism Program Digital Information Series, GVP-3, (http://www.volcano. si.edu/world/)

Ter Braak CJF, Smilauer P (2002) CANOCO reference manual and user's guide to canoco for windows: software for canonical community ordination (version 4.5). Microcomputer Power, Ithaca

Teranes JL, McKenzie JA, Bernasconi SM, Lotter AF, Sturm M (1999) A study of isotopic fractionation during biinduced calcite precipitation in eutrophic Baldeggersee, Switzerland. Geochim Cosmochim Acta 63:1981-1989

Uribe-Cifuentes RM, Urrutia-Fucugauchi J (1999) Paleomagnetic study of the Valle de Santiago volcanics, MichoacánGuanajuato volcanic field, Mexico. Geofisica Internacional 38:217-230

Valero-Garcés BL, Kelts KR (1995) A sedimentary facies model for perennial and meromictic saline lakes: Holocene medicine Lake Basin, South Dakota, USA. J Paleolimnol 14: 123-149

Valero-Garcés BL, Kelts K, Ito E (1995) Oxygen and carbon isotope trends and sedimentological evolution of a meromictic and saline lacustrine system: the Holocene Medicine Lake basin, North American Great Plains, USA. Palaeogeogr Palaeoclimatol Palaeoecol 117:253-278

Varekamp JC, Luhr JF, Prestegaard KL (1984) The 1982 eruptions of El Chichón volcano (Chiapas, Mexico): character of the eruptions, ash-fall deposits, and gasphase. J Volcanol Geotherm Res 23:39-68

Waitz P (1915) El estado Actual de los Volcanes de México y la Última Erupción del Volcán de Colima (1913). Revista Volcanológica: 259-268

Warthmann R, van Lith Y, Vasconcelos C, McKenzie JA, Karpoff AM (2000) Bacterially induced dolomite precipitation in anoxic culture experiments. Geology 28:1091-1094

Wilcox RE (1954) Petrology of Paricutín Volcano, Mexico. US Geol Surv Bull 965-C:281-353

Williams SN, Self S (1983) The October 1902 plinian eruption of Santa Maria volcano, Guatemala. J Volcanol Geotherm Res 16:33-56

Wray JL, Daniels F (1957) Precipitation of calcite and aragonite. J Am Chem Soc 79:2031-2034

Yarza de De la Torre E (1971) Volcanoes of Mexico. Aguilar, Mexico City, p 237

Zolitschka B, Brauer A, Negendank JFW, Stockhausen H, Lang A (2000) Annually dated Weichselian continental paleoclimate record from the Eifel, Germany. Geology 28:783-786 